\title{
パルプのヘキセンウロン酸含有量と 加速劣化における白色度安定性の関係
}

\section{Relationship between Hexenuronic Acid Content of Pulp and Brightness Stability in Accelerated Aging}

筑波大学 ${ }^{* 1}$ 大学院生命環境科学研究科

桑原英子，周 欣，本間光子， 高橋史帆a)，梶山幹夫，大井 洋*2

Eiko Kuwabara, Xin Zhou, Mitsuko Homma, Shiho Takahashi ${ }^{\text {a) }}$, Mikio Kajiyama and Hiroshi Ohi ${ }^{* 2}$

Graduate School of Life and Environmental Sciences, University of Tsukuba*1

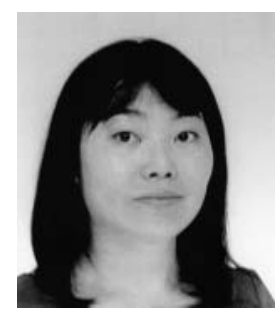

桑原英子

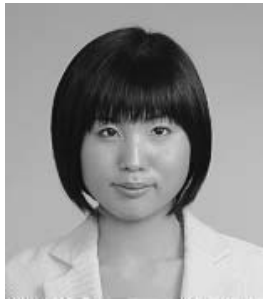

高橋史帆

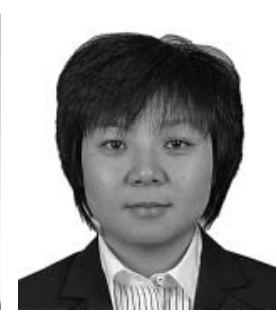

周 欣

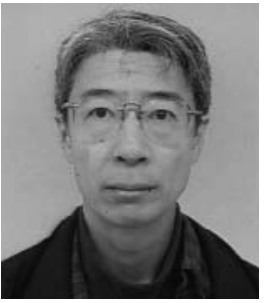

梶山幹夫

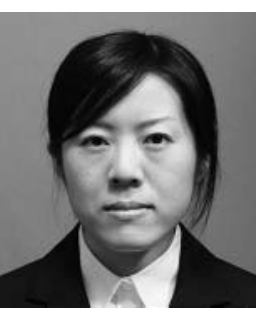

本間光子

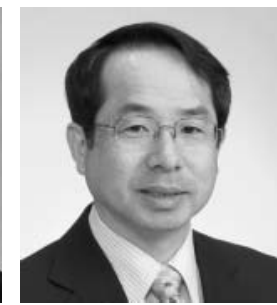

大井 洋

Abstract

Six types of pulps that were prepared under acidic or neutral papermaking conditions, were investigated about behavior of yellowing or the others after accelerated aging tests. The relationship between the hexenuronic acid (HexA) content of pulps and yellowing was clarified for non-chlorine-bleached pulps (elemental chlorine-free (ECF) and totally chlorine-free (TCF) bleached pulps) prepared from hardwood oxygen-bleached kraft pulp (LOKP). A trial test of enzymatic removal of HexA from LOKP was attempted by treatment with a crude enzyme solution containing a new hexenuronidase.

The results indicated that the brightness reversion of LOKP that was prepared by acidic papermaking and underwent a humid accelerated aging test was greater than that of LOKP that underwent a dry accelerated aging test. On the other hand, the brightness of LOKP increased after sunlight exposure aging test. Under sunlight exposure, the structure of the lignin in bleached thermomechanical pulp (TMP) and bleached chemical thermomechanical pulp (BCTMP), which is similar to the lignin in wood, changed to coloring structures. However, the effect of this change on brightness reversion was minimal in acidic papermaking. Plain paper copier (PPC)

\footnotetext{
${ }^{* 1}$ × 305-8572 茨城県つくば市天王台 1-1-1/1-1-1 Tennodai, Tsukuba-shi Ibaraki 305-8572, Japan

${ }^{* 2} \mathrm{E}-$ mail : oi.hiroshi.gm@u.tsukuba.ac.jp

a)現在の所属：ニューブランズウィック大学/Current address：Department of Chemical Engineering, University of New Brunswick, Canada
} 
paper and news printing (NP) paper, which are prepared by mixing used paper with secondary fibers, were assumed to consist of both chemical and mechanical pulps and therefore showed a relatively stable brightness in spite of accelerated aging conditions and $\mathrm{pH}$ in papermaking.

Under conditions of neutral papermaking, LOKP showed the least brightness reversion and the brightness of TCF and ECF pulps were similar to each other. On the other hand, the yellowing of TCF and ECF pulps prepared in acidic papermaking tended to increase with the increase in HexA content of the pulps. In addition, the pulps had the following order of good brightness stability : full-bleached TCF, full-bleached ECF, semi-bleached TCF, and LOKP.

HexA removal from LOKP with crude enzymes solution containing hexenuronidase (activity for $\Delta-\mathrm{X}_{3}: 2^{-}$ $O-(\alpha$-hexenuronic acid $)-\mathrm{D}^{-}$xylotriose $)$was optimum under the following treatment conditions $: 0.24 \mathrm{U} / \mathrm{g}, \mathrm{pH}$ $5.5,40^{\circ} \mathrm{C}$, and $6 \mathrm{~h}$. It was shown that $40 \mathrm{mmol} / \mathrm{kg}$ of xylose was dissolved into the filtrate when $20 \mathrm{mmol} / \mathrm{kg}$ of HexA was removed from the pulp; however, the decrease in the pulp yield was minimal.

Keywords : mechanical pulp, chemical pulp, hexenuronidase, enzyme, brightness stability

分類 : $\mathrm{K}_{12}$ 無塩素漂白, $\mathrm{Y}_{3}$ リグニン化学, $\mathrm{K}_{11}$ 酵素処理（および微生物漂白）

\section{1. 緒言}

パルプは，製造方法によって機械パルプ（Mechanical pulp）と化学パルプ（Chemical pulp）に大別される。機 械パルプは, 丸太やチップに湿潤状態でせん断力を加える ことにより木材繊維を離解する方法で, 砕木パルプ (Groundwood pulp), サーモメカニカルパルプ (Thermomechanical pulp), セミケミカルパルプ (Semi-chemical pulp）などがある。化学パルプは，木材組織中に含まれる リグニンを化学的に分解溶出させて木材繊維を単離する方 法で, クラフトパルプ(Kraft pulp), 亜硫酸パルプ (Sulfite pulp）などがある。

本来，木材は再生可能な資源であるが，森林の成長量を 超えた量の木材が伐採されると森林破壊を引き起こす可能 性がある。紙のリサイクルを推進すれば, 古紙を利用した 分だけ木材消費量が減少し, 森林保護に寄与すると考えら れている。製紙の有効な原料として, ある程度の高い白色 度を保ちつつ, 工程の機械的処理に耐えうる強度を保った 古紙が用いられる。現在, 古紙利用は中国などを中心に急 激に増加する傾向にあり, その品質とリサイクル特性につ いてさらに詳細な検討を行うことが重要である。

無塩素漂白パルプは, 塩素を用いずに漂白したパルプで あり, 漂白工程でダイオキシン類などの有害な塩素化合物 の発生が抑えられる。無塩素漂白パルプは大きく分けて, $\mathrm{ECF}$ 漂白と TCF 漂白の二つに分類される。ECF 漂白は 塩素の代わりに二酸化塩素（塩素元素を含む漂白剂）を使 用する方法であり, 完成した紙と廃水には微量の塩素化合 物が残る。TCF 漂白は塩素や塩素元素を含む漂白剂を一 切使用しない方法であり, 酸素, オゾン, 過酸化水素など の漂白剤を使用している。また，無塩素漂白においても， パルプ繊維を過度に傷めないで, 比較的に強勒なパルプを 作ることが可能になり, これらのパルプはリサイクルに適 したパルプとも言える。

人間の視覚に感ずる可視光線の波長は 400-700 nm の範 囲であり，目に対する刺激の強さを視感度という。製紙工
業においては, $457 \mathrm{~nm}$ の波長の光線を用いて, その反射 率を基準として白さの尺度としている。白色度と視感度は, 異なる波長を基準にしているので，パルプの光学的な品質 評価と視覚的な品質評価は必ずしも一致しない。炭水化物 は本来白色であり, パルプの白色度はリグニン, 樹脂など の着色性不純物を脱色するか，あるいは除去することによ って上昇する。

リグニンはフェニルプロパンを基本構造単位とする複雑 な高分子物質で, 潜在的な発色基としての官能基を持つ。 木材のプロトリグニンは変質しない状態で，70\% ISO 程 度の白色度を持つクリーム色を呈している。これが, 空気 の酸化作用, パルプ化工程における諸作用によって変質し, 発色構造に移行して白色度の低下をもたらす ${ }^{1)} 。$

漂白工程の目的は, 高白色度の紙を作るためにパルプ中 に残存する着色物質であるリグニンを取り除くことである。 現在，パルプ中に残存するリグニン量を表す指標としてカ ッパー価が広く用いられており，一般にカッパー価の高い パルプほど残存するリグニン量が多く, 低いパルプほど残 存するリグニン量が少ない。カッパー価の測定には過マン ガン酸カリウムが用いられ, 残存リグニンの酸化分解のた めに消費された過マンガン酸カリウムの消費量よりカッパ 一価が求められる。

Vuorinen $^{2)}$, Gellerstedt $t^{3)}$ は, パルプ中の残存リグニ ンだけでなくへキセンウロン酸（以下 HexA とする）も カッパー価に影響を与えることを報告した。HexA が分子 中に二重結合をもつことから，カッパー価測定時に用いら れる過マンガン酸カリウムを消費するために測定值に影響 を与える。HexA は天然の材中には存在せず, クラフト蒸

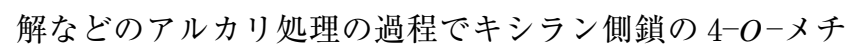
ル-D-グルクロン酸残基より生成する（Fig. 1）。また，ア ルカリ蒸解条件で安定であるために蒸解後のパルプに残存 することが報告されている゙4。

HexA は塩素 $\left(\mathrm{Cl}_{2}\right)$ を用いた漂白処理により速やかに 分解される。しかし, 現在, 主流となっている ECFまた は TCF 漂白では, HexA は分解されにくく, 製紙の最終 

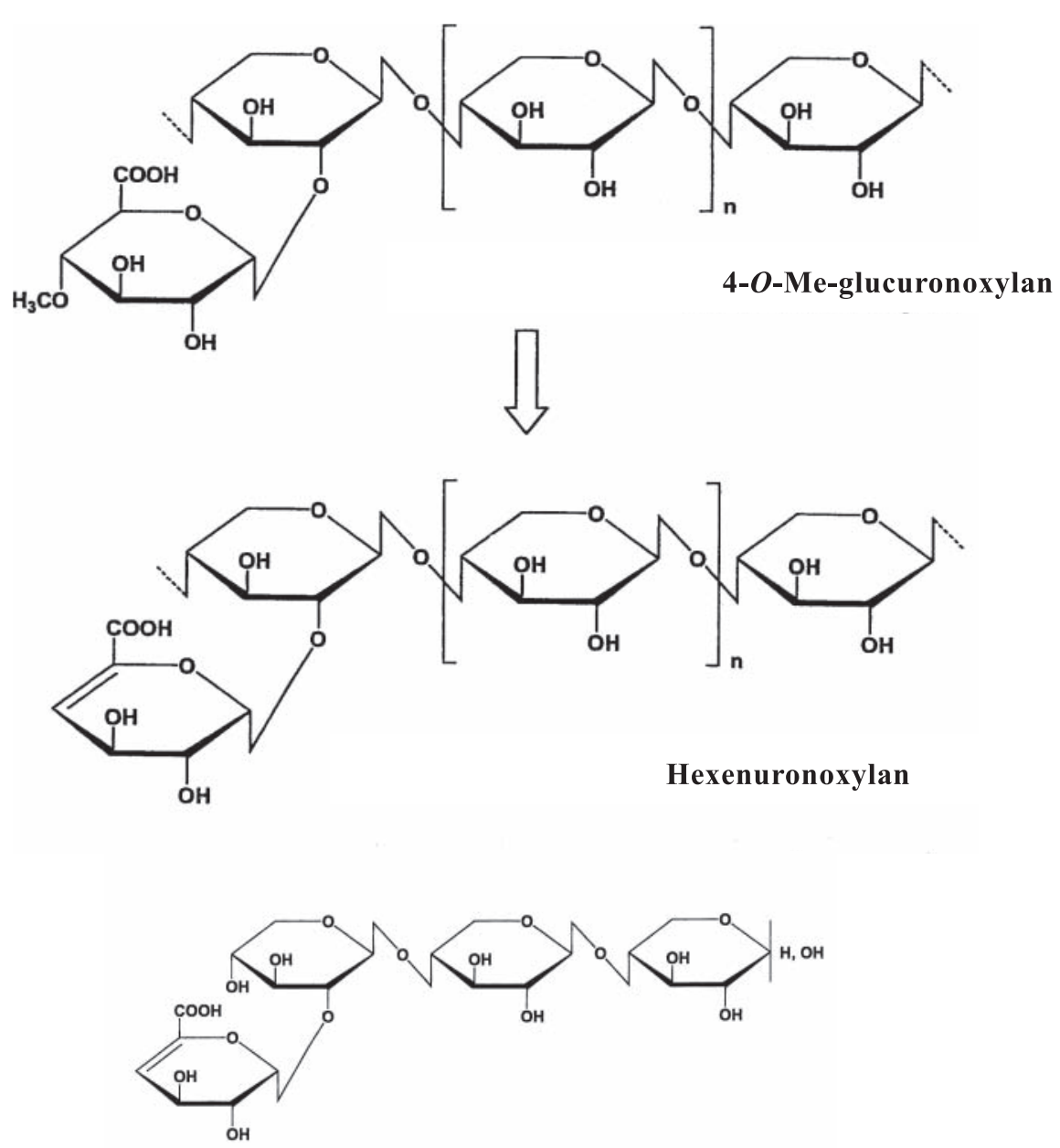

$\Delta-\mathrm{X}_{3}(\mathrm{n}=1)$

Fig. 1 Conversion of $4-O-\mathrm{Me}^{-}$glucuronoxylan to hexenuronoxylan during kraft cooking and $\Delta-\mathrm{X}_{3}(\mathrm{n}=1)$ prepared from pulp

工程まで残留する。また，二重結合を持つ HexA はオゾ ンなどの漂白片を消費してしまう。

紙の白色度安定性と漂白パルプに含まれるHexA 含有 量の間には強い相関があると報告されている5)。HexA は 加水分解により 2-フランカルボン酸 (FA）と5-ホルミル -2-フランカルボン酸（FFA）を約 $9: 1$ の割合で生成す $3^{6)}$ 。このうち, 白色度の低下 (黄変) に大きな影響を及 ぼすのは FFA であり, また，パルプ中に鉄イオンが存在 することにより黄変が促進されることも報告されている》。 白色度低下の原因物質として, パルプに含まれる残存リグ ニンあるいは炭水化物に由来する化合物 ${ }^{8,9}$ なども報告され ている。

桑原ら ${ }^{10)}$ は, 工場から採取した広葉樹材酸素漂白クラフ トパルプ（LOKP）を用いて1）ECF 漂白・酸性抄紙，2） TCF 漂白・酸性抄紙，3） ECF 漂白・中性抄紙，4） TCF 漂白・中性抄紙を行い, それぞれの漂白・抄紙方法で HexA 含有量の異なるパルプを調製し, 黄変の程度を比較 した。同じ HexA 含有量における黄変は，1）４）の順に 大きく, 顕著な差が認められることを示した。酸性抄紙で はサイズ剤, 定着剤として硫酸バンドを用いる。桑原ら ${ }^{10)}$
は，硫酸バンドに含まれるアルミニウムイオンおよび漂白 パルプに微量に残る鉄イオンがHexA 分解生成物と錯体 を形成し，黄変すると考察している。

パルプ中の HexA 含有量は白色度安定性に大きな影響 を与えるので, パルプ中の HexA を除去する方法が重要 な課題となっている。従来の酸処理による方法では, HexA だけではなく他の物質も酸の影響で分解し，パルプ品質の 低下が懸念された。そこで, 選択的かつ温和な条件下での 処理方法の開発が求められている。

この条件の处理の一つとして, 酵素反応を用いる処理が 適していると期待される。しかし，パルプ中の HexAの 酵素による特異的な除去についての研究報告はない。五味 ら ${ }^{11)}$ は新規 HexA 遊離酵素（ヘキセンウロニダーゼ）を生 産する菌を土壌中から見出し, Paenibacillus sp. 07-G- $\mathrm{dH}$ と命名した。この株の菌体より粗䤉素液が分離抽出された。 この酵素の生化学的特徴などについては現在解明がすすん でいる。粗酵素液中のへキセンウロニダーゼは至適 $\mathrm{pH}$ が 6. 5-7.0, 最適温度が $35-40^{\circ} \mathrm{C}$ であることも明らかになっ ている。酵素活性は $\mathrm{pH} 5.0-8.0,30^{\circ} \mathrm{C}, 12$ 時間の処理に 対して安定であり，また $50{ }^{\circ} \mathrm{C} ， 20$ 分間の熱処理で約 $60 \%$ 
の活性を保持し， $60^{\circ} \mathrm{C}, 20$ 分間の熱処理で完全に失活す ることがわかっている。しかし，このような酥素のパルプ 漂白に対する実用的な試験については，まだ報告がない。

そこで本研究では，まず，白色度 70-88\% ISO の原料に 着目し，六種類のパルプを中性または酸性で抄紙し，加速 劣化処理による黄変挙動等について検討を行った。つぎに, LOKP から調製した ECF およびTCF 漂白パルプについ て, パルプの HexA 含有量と黄変挙動との関係について 検討を加えた。さらに，新規へキセンウロニダーゼを含む 粗酵素液によるパルプの HexA 除去について, 探索試験 を行った。

\section{2. 実験}

\section{1 試料}

王子製紙株式会社より恵与された LOKP（以下 LOKP1 と呼ぶ), 北越製紙株式会社新潟工場より恵与された LOKP (以下 LOKP-2 と呼ぶ), 日本紙パルプ研究所より 恵与された針葉樹材漂白サーモメカニカルパルプで乾燥し たパルプ (TMP)，中国の製紙工場から恵与されたカナダ 産の広葉樹材漂白ケミサーモメカニカルパルプで乾燥した パルプ (BCTMP), 市販されている古紙配合コピー用紙 (PPC)，および各社新聞古紙の印刷のない部分 (NP) を 解繊したパルプを実験に用いた。

\section{2 過酸化水素漂白 $(\mathrm{P})$}

ビニール袋の中で, LOKP（絶乾換算 $5 \mathrm{~g}$ ) に所定量の $30 \% \mathrm{H}_{2} \mathrm{O}_{2}$ 水溶液（対パルプ添加率 $1 \%$ ), および $4 \mathrm{~mol} / \mathrm{L}$ の $\mathrm{NaOH}$ 水溶液（対パルプ添加率 $0.8 \%$ ）を加え, 蒸留水 を入れてパルプ濃度を $10 \%$ に調整した。十分混ぜてから $70^{\circ} \mathrm{C}, 1$ 時間の加温処理を一回行った。過酸化水素漂白を 一回行ったパルプを semi-TCF，同様の処理を三回行って 漂白したパルプを full-TCF と呼ぶ。漂白後のパルプを水 で十分洗浄し，パルプシートを作製した。

\section{3 二酸化塩素漂白 (D)}

ポリ塩化ビニリデン製袋の中に，パルプ（絶乾換算 $5 \mathrm{~g}$ ) とカッパーファクター (KF) 0.05-0.20 となる量の二酸 化塩素水溶液を加え（パルプのカッパー価 $\times \mathrm{KF}=$ 有効塩 素の添加率), 蒸留水を入れてパルプ濃度 $10 \%$ に調整した。 十分混ぜてから $60^{\circ} \mathrm{C}, 1$ 時間の加温処理を行った。漂白後 のパルプを水で十分洗浄し，パルプシートを作製した。

\section{4 酸処理 (A)}

ビニール袋の中で，パルプ（絶乾換算 $5 \mathrm{~g} ） に 1 \mathrm{~mol} / \mathrm{L}$ の希硫酸（対パルプ添加率 1.5\%）を加え, 蒸留水を入れ て，またパルプ懸濁液の $\mathrm{pH}$ を 2.5-3, パルプ濃度 $10 \%$ に 調整した。十分混合してからオートクレーブ中 $105^{\circ} \mathrm{C} て ゙, 1$ 時間, 2 時間および 3 時間の酸处理を行った。処理後のパ ルプを水で十分洗浄し, 吸引ろ過で脱水して, パルプシー トを作製した。

\section{5 酸性抄紙}

パルプ（絶乾換算 $5 \mathrm{~g}$ ）を $400 \mathrm{~mL}$ の水に解緎して，10\% $\mathrm{Al}_{2}\left(\mathrm{SO}_{4}\right)_{3}$ 水溶液を加え, $\mathrm{pH}$ メーターを用いて $\mathrm{pH}$ を 4.4 または 3.9 に調整した。 $\mathrm{pH} 4.4$ の場合, $10 \% \mathrm{Al}_{2}\left(\mathrm{SO}_{4}\right)_{3}$ 水 溶液の添加量は約 $2 \mathrm{~mL}$ で，また，pH 3.9 の場合は $10 \%$
$\mathrm{Al}_{2}\left(\mathrm{SO}_{4}\right)_{3}$ 水溶液の添加量は約 $4 \mathrm{~mL}$ であった。パルプ懸 だく液を TAPPI 標準手抄機のシリンダー $(155 \mathrm{~mm} \phi$ 用 $)$ に入れて，パルプシートを作製した。中性抄紙では，パル プを洗浄後, $\mathrm{Al}_{2}\left(\mathrm{SO}_{4}\right)_{3}$ 水溶液を加えずにろ過水でパルプ シートを作製した。

\section{6 加速劣化処理}

1）湿式加速劣化（以下, Humid と呼ぶ）：パルプシー 卜を $80^{\circ} \mathrm{C}$, 相対湿度 $65 \%$ の条件で， 24 時間保持する 加速劣化試験（JIS P 8154-3）を行った。

2）乾式加速劣化 - 加熱劣化（以下, Dry-1 と呼ぶ)： パルプシートを $105^{\circ} \mathrm{C}$, 相対湿度 $0 \%$ の条件で 24 時 間処理した。

3）乾式加速劣化 - 日光照射劣化（以下, Dry-2 と呼 ぶ）：パルプシートを室外温度 $15^{\circ} \mathrm{C} \sim 30^{\circ} \mathrm{C} て ゙ ， 10$ 時 間太陽光に照射した。

加速劣化処理の前後のパルプシートについて, デジタル カラーメーター（東京電色製 Model TC-3600, TC-1500 SXIII）を用い, ISO 白色度と PC 価（Post color number） を求めた。

\section{$2.7 \mathrm{PC}$ 価の算出}

白色度低下の評価基準として, 単純には白色度低下幅が 考えられる。一方, 加速劣化試験の前後の白色度から, PC 価（Post color number）を次式によって求めた。

$\mathrm{PC}$ 価 $=100\{(\mathrm{~K} / \mathrm{S}) \mathrm{a}-(\mathrm{K} / \mathrm{S}) \mathrm{b}\}, \mathrm{K} / \mathrm{S}=(1-\mathrm{R}) 2 / 2 \mathrm{R}$

$\mathrm{R} ： 457 \mathrm{~nm}$ の波長で測定した白色度（\%) $\div 100$

$\mathrm{K}$ : 比吸収係数, $\mathrm{S}$ : 比散乱係数, $\mathrm{a}$ : 退色後, $\mathrm{b}$ : 退色前

\section{8 パルプの HexA 分析}

パルプ中の HexA 含有量は, ヘルシンキ工科大学の選 択的加水分解 ${ }^{12}$ に準じて定量した。変更点は, パルプの加

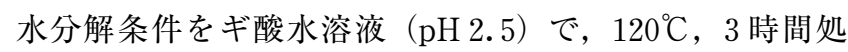
理する条件にした点である。酸加水分解物を含むギ酸水溶 液をHPLCに供してFA拈よび FFA を分離し， $265 \mathrm{~nm}$ に扔ける UV 吸光度を用いて定量した。標品水溶液から作 製した検量線により, FA と FFAの生成量を求めて, そ の合計量をHexA 量とした。HPLCの条件を以下に示す。

HPLC ポンプ : GL Sciences PU 614

検出器: GL Sciences UV 620

カラム : ZORBAX COLUMN (ODS, 内径 $4.6 \mathrm{~mm}$, 長 さ $25 \mathrm{~cm}$ )

流速: $0.5 \mathrm{~mL} / \mathrm{min}$, カラム温度 : $40^{\circ} \mathrm{C}$, 流入量 $: 10 \mu \mathrm{L}$ 溶離液：ギ酸とアセトニトリルの混液 $(4: 1 \mathrm{v} / \mathrm{v}, \mathrm{pH}$ 2.5)

\section{9 パルプ粘度（銅エチレンジアミン法）}

パルプ (絶乾換算 $0.125 \mathrm{~g}$ )に $10 \mathrm{~mL}$ の水を加え, 5 分 間㩭拌し, 次に $0.5 \mathrm{~mol} / \mathrm{L}$ 銅エチレンジアミン水溶液 $5 \mathrm{~mL}$ を加え 5 分間攪拌した。さらに, $1 \mathrm{~mol} / \mathrm{L}$ 銅エチレンジア ミン水溶液 $10 \mathrm{~mL}$ を加えて 15 分間攪挥した後, その溶液 から約 $10 \mathrm{~mL}$ をャノンフェンスケ型粘度計に移した。粘 度計をホルダーに取り付け, $25^{\circ} \mathrm{C}$ の水槽につけ， 5 分ほど 置いてから，溶液を吸い上げ， 2 本の標線間を通過する時 間を計った。パルプ粘度 $\eta(\mathrm{cP}=\mathrm{mPa}(\mathrm{s})$ を次式で求めた。 以上の方法は, JAPAN TAPPI No.44 に準じた方法であ 
る。

$\eta=\mathrm{Ctd}$

$\mathrm{C}$ : 粘度計定数, $\mathrm{t}$ : 溶液の流下時間（秒， $\mathrm{d} ：$ 溶液の密 度 $\left(1.052 \mathrm{~g} / \mathrm{cm}^{3}\right)$

2.10 カッパー価の測定方法

パルプのカッパー価を TAPPI Test Method T $236 \mathrm{~cm}^{-}$ 85 にしたがって測定した。

\subsection{1 酵素処理の試料}

LOKP-2 を用い，供試菌株は土壤中より分離，同定し たPaenibacillus sp. $07-\mathrm{G}-\mathrm{dH}$ 株を用いた。

\subsection{2 菌体内酵素の抽出}

容量 $500 \mathrm{~mL}$ の瓶二つに, $0.5 \%$ xylan（カバ材由来, Fluka 製)，0.1\% yeast extract，0.1\% polypepton，0.1\% $\mathrm{KH}_{2} \mathrm{PO}_{4}, 0.1 \% \mathrm{MgSO}_{4} \cdot 7 \mathrm{H}_{2} \mathrm{O}, 0.1 \%$ yeast (nitrogen base), $\mathrm{pH} 7.0$ となるように調整した液体培地を各 100 $\mathrm{mL}$ 用意し, 斜面培地より白金耳分を植菌した。これを $30^{\circ} \mathrm{C}$ で 48 時間振とう培養し，さらに同じ成分の培養液 $3 \mathrm{~L} に$ 移し，ミニジャー・ファーメンターを用いて， $30^{\circ} \mathrm{C} ， 24$ 時間攪拌培養し続けた。培養液を遠心分離（7,000 xg，30 分間）して菌体ペレットを乳鉢にとって適量の酸化アルミ ニウム（Wako, 細胞破砕用）を加え, 水冷しながら乳棒 で 30 分間すり潰した。これに $20 \mathrm{mM}$ リン酸ナトリウム 緩衝溶液 $(\mathrm{pH}$ 6.5) を加元，30 分間攪拌，遠心分離 $(7,000$ $\mathrm{xg} ， 30$ 分間）を行って，上澄みを粗酵素液(1)とした。粗 酔素液(1)をさらに遠心分離（12,000 xg，50 分間）した後, Amicon YM-10（Millipore）を用いて限外滤過し，遠心分 離 $(12,000 \mathrm{xg}, 50$ 分間) して上澄みをとって各種操作に 用いた。本研究では，この上澄みを粗酵素液(2) と呼ぶ。

\subsection{HPAEC-PAD 法による活性測定}

活性測定の基質には Fig. 1 に示す化合物 $\Delta-X_{3}$ を用いた。 これは, キシロース 3 量体にへキセンウロン酸残基が結合 するオリゴマーである。活性測定では, $2 \mathrm{mM} \Delta-\mathrm{X}_{3}$ 溶液 $0.1 \mathrm{~mL}$ に粗酵素液(2) $0.1 \mathrm{~mL}$ を加え, $35^{\circ} \mathrm{C}$ で 30 分間反応 させた。反応後, $100^{\circ} \mathrm{C}$ で 5 分間加熱し, 䣲素を失活させ た。反応液に水冷したアセトン $0.8 \mathrm{~mL}$ を加えて攪拌し, エッペンドルフチューブに移し，遠心分離 $(12,000 \mathrm{xg}, 10$ 分間）した。上澄みを減圧乾固し， $2 \mathrm{~mL}$ の蒸留水に溶解， 分析試料とした。

クラフトパルプの酵素加水分解液中の $\Delta-\mathrm{X}_{3}$ については, Telman ら ${ }^{13)}$ あるいは Ishihara ら ${ }^{14)}$ 等よって分析が行われ た。本研究では HPAEC-PAD 法（高速陰イオン交換クロ マトグラフィー・パルスドアンペロメトリー検出法）によ って定量分析した。HPAEC-PAD の条件を以下に示す。

装置：DIONEX（ICS-3000，Sunnyvale，CA，USA） 検出: 電気化学検出器 (ED : electrochemical detector) カラム：IonPac AS 7 陰イオン交換カラム（内径 $4 \mathrm{~mm}$,

長さ $25 \mathrm{~cm}$ ), IonPac AS 7 ガードカラム (内径 $4 \mathrm{~mm}$, 長さ $5 \mathrm{~cm}$ )

カラム温度： $30^{\circ} \mathrm{C}$, 流速 $: 1.0 \mathrm{~mL} / \mathrm{min}$

溶離液： $0.1 \mathrm{~N}$ 水酸化ナトリウム（溶離液 $\mathrm{A}$ ），0.1 N 水酸化ナトリウム $/ 1.0 \mathrm{M}$ 酢酸ナトリウム（溶離液 B) グラジエント：開始時は溶離液 A：100\%，15 分後に溶
離液 A：70\%，溶離液 B：30\% となるように調整した。 活性は 1 分間に $1 \mu \mathrm{mol}$ の $\Delta-\mathrm{X}_{3}$ を分解する酥素量を 1 Unit（U）とした。本研究では，この活性をへキセンウロ ニダーゼ活性と呼ぶ。

\subsection{4 パルプの酵素処理}

$\mathrm{L}$ 字試験管に, $1 \mathrm{~g}$ (絶乾換算) のパルプに対して，へ キセンウロニダーゼ $0 ， 0.08 ， 0.16 ， 0.20 ， 0.24$ あるいは $0.28 \mathrm{U}$ を含む粗酵素液, 微量の蒸留水, および $50 \mathrm{mM}$ 酢 酸/酢酸ナトリウム緩衝溶液（pH 5.5）を加え，パルプ濃 度を $5 \%$ に調整した。十分混ぜてから $40^{\circ} \mathrm{C} ， 3-12$ 時間で 振とう処理した。処理後のパルプを吸引ろ過し，万液を採 取して適切な濃度に希釈し, 前述の HPAEC-PAD 法によ り定量分析した。一方，パルプは水で十分洗浄し，ハンド シートを作製した。風乾パルプの重量と水分補正率を測っ てパルプ収率 (絶乾収率) を求めた。風乾パルプの一部 (絶 乾換算 $0.8 \mathrm{~g}$ ) を用いて, 加水分解後, HPLCでFA およ び FFA を定量し，パルプ中の HexA の残存量を求めた。

\section{3. 結果と考察}

\section{1 試料の性質}

供試パルプの白色度, HexA 含有量, パルプ粘度, カッ パー価を Table 1 に示す。広葉樹材酸素漂白クラフトパル プ LOKP-1 と LOKP-2 は, HexA 含有量が高く, カッパ 一価が比較的低い。漂白された TMP と BCTMP のリグニ ン含有量は高いが，白色度が高く，HexA 含有量は低い。 古紙パルプとしての PPC は NPよりカッパー価が低く, 化 学パルプの配合率が高いと考えられる。

\section{2 各試料の加速劣化による黄変}

六種類の試料について, 各条件 (Humid：湿式, Dry -1 ： 乾式, Dry-2：日光照射）における加速劣化処理前後の白 色度の差（ $\Delta \% \mathrm{ISO}$ ）を Table 2 に示す。退色性の評価基 準である PC 価を Fig. 2 - 4 に表示する。HexA 含有量が 高い LOKP-1 と LOKP-2 の湿式劣化では, 乾式の二つの 条件に比べると著しい黄変を示した。酸性抄紙（pH 3.9） 条件では白色度に 9 ポイントの低下がみられ，PC 価は最 大 6.8 であった。クラフトパルプに含まれるHexA は湿 式劣化条件でアルミニウムまたは鉄と錯体を形成し，着色 構造に変化することが報告されている ${ }^{10)}$ 。本実験の結果か らも，硫酸アルミニウムの添加量が多いほど退色が大きく なることが明らかになった。

また，LOKP-1 と LOKP-2 に日光照射を行うと白色度 が向上する現象が認められた。 LOKP と機械パルプで ある TMP，BCTMP の日光照射における退色挙動を比較 すると, LOKP の白色度は最大で 2.6 ポイント向上し, 機 械パルプの白色度は低下している。木材とほぼ同じ化学構 造を有する TMP と BCTMP パルプ中のリグニンは着色構 造に変化したことが示唆される。TMP と BCTMPに対し て，日光照射では，酸性抄紙にすることによる白色度低下 への影響はあまり大きくなかったが，乾式条件の加速劣化 では，顕著な退色性が現れた。

古紙含有の PPC と NP では，湿式および乾式加速劣化 の両方ともほぼ同じ程度の黄変を示し，化学パルプと機械 
Table 1 Characteristics of pulp materials

\begin{tabular}{|c|c|c|c|c|c|c|}
\hline \multirow{2}{*}{$\begin{array}{c}\text { Name } \\
\text { LOKP-1 }\end{array}$} & \multicolumn{2}{|c|}{ Species } & \multirow{2}{*}{$\begin{array}{c}\begin{array}{c}\text { Brightness } \\
(\% \mathrm{ISO})\end{array} \\
64.1\end{array}$} & \multirow{2}{*}{$\begin{array}{c}\text { HexA } \\
(\mathrm{mmol} / \mathrm{kg})\end{array}$} & \multirow{2}{*}{$\begin{array}{c}\text { Viscosity } \\
(\mathrm{cP})\end{array}$} & \multirow{2}{*}{$\begin{array}{c}\begin{array}{c}\text { Kappa } \\
\text { number }\end{array} \\
12.3\end{array}$} \\
\hline & Hardwood & $\mathrm{O}_{2}$-bleached kraft & & & & \\
\hline LOKP-2 & Hardwood & $\mathrm{O}_{2}$-bleached kraft & 71.0 & 46.2 & 20.2 & 9.1 \\
\hline TMP & Softwood & Thermomechanical & 79.1 & 5.41 & - & 124 \\
\hline ВСТМР & Hardwood & $\begin{array}{c}\text { Bleached } \\
\text { thermomechanical }\end{array}$ & 82.4 & 4.07 & - & 126 \\
\hline PPC & Secondary, Mixed & $\begin{array}{c}\text { Plain paper copier } \\
\text { containing recycled fiber }\end{array}$ & 72.2 & 8.76 & - & 31.1 \\
\hline NP & Secondary, Mixed & $\begin{array}{l}\text { Newspaper printing } \\
\text { containing recycled fiber }\end{array}$ & 57.8 & 5.87 & - & 52.9 \\
\hline
\end{tabular}

Table 2 Brightness reversion of various pulps which were treated by three kinds of accelerated aging tests after neutral or acidic papermaking conditions

\begin{tabular}{|c|c|c|c|c|c|}
\hline \multirow[b]{2}{*}{ Pulp } & \multirow{2}{*}{$\begin{array}{c}\mathrm{pH} \text { of } \\
\text { papermaking }\end{array}$} & \multirow{2}{*}{$\begin{array}{c}\text { Brightness } \\
\text { (\% ISO) }\end{array}$} & \multicolumn{3}{|c|}{ Brightness reversion $(\Delta \%$ ISO $)$} \\
\hline & & & Humid & Dry -1 & Dry -2 \\
\hline \multirow{3}{*}{ LOKP-1 } & pH 7.0 & 64.1 & -0.9 & 0.3 & 2.6 \\
\hline & $\mathrm{pH} 4.4$ & 66.4 & -4.7 & -0.9 & 1.7 \\
\hline & pH 3.9 & 67.6 & -9.0 & -1.6 & 1.4 \\
\hline \multirow{3}{*}{ LOKP-2 } & pH 7.0 & 71.0 & -0.4 & -0.7 & 0.6 \\
\hline & $\mathrm{pH} 4.4$ & 72.4 & -1.1 & -1.0 & 0.7 \\
\hline & $\mathrm{pH} 3.9$ & 73.4 & -4.7 & -1.2 & 0.3 \\
\hline \multirow{3}{*}{ TMP } & pH 7.0 & 79.1 & -2.3 & -3.3 & -5.9 \\
\hline & $\mathrm{pH} 4.4$ & 78.9 & -1.9 & -3.8 & -5.7 \\
\hline & pH 3.9 & 79.1 & -2.4 & -8.7 & -5.5 \\
\hline \multirow{3}{*}{ ВСТMP } & $\mathrm{pH} 7.0$ & 82.4 & -2.8 & -2.1 & -12.8 \\
\hline & $\mathrm{pH} 4.4$ & 82.5 & -1.9 & -2.2 & -13.0 \\
\hline & $\mathrm{pH} 3.9$ & 82.2 & -1.6 & -4.0 & -11.1 \\
\hline \multirow{3}{*}{$\mathrm{PPC}$} & pH 7.0 & 72.2 & -1.3 & -0.3 & -4.1 \\
\hline & $\mathrm{pH} 4.4$ & 72.0 & -1.6 & -1.3 & -3.8 \\
\hline & pH 3.9 & 71.8 & -1.8 & -2.0 & -3.4 \\
\hline \multirow{3}{*}{ NP } & $\mathrm{pH} 7.0$ & 57.8 & -1.5 & -0.3 & -0.5 \\
\hline & $\mathrm{pH} 4.4$ & 57.9 & -1.5 & -0.4 & -1.3 \\
\hline & pH 3.9 & 56.8 & -1.6 & -0.4 & -1.2 \\
\hline
\end{tabular}

Legend: Three kinds of accelerated aging tests

Humid : $80^{\circ} \mathrm{C}, 65 \% \mathrm{RH}, 24 \mathrm{~h}$

Dry $-1: 105^{\circ} \mathrm{C}, 0 \% \mathrm{RH}, 24 \mathrm{~h}$

Dry $-2: 15-30^{\circ} \mathrm{C}, 10 \mathrm{~h}$ under sunlight

パルプの両方が配合されている特徴が認められた。LOKP と TMP の白色度低下幅に比べると, 古紙含有の PPC と $\mathrm{NP}$ は, 劣化処理の条件や抄紙時の $\mathrm{pH}$ にかかわらず，比
較的一定の白色度を保持した。

3.3 加速劣化による LOKP のパルプ粘度変化 パルプ粘度はパルプ繊維の崩壊, セルロースの劣化とパ 


\section{LOKP-1}

$\square \mathrm{pH} 3.9 \square \mathrm{pH} 4.4 \square \mathrm{pH} 7.0$

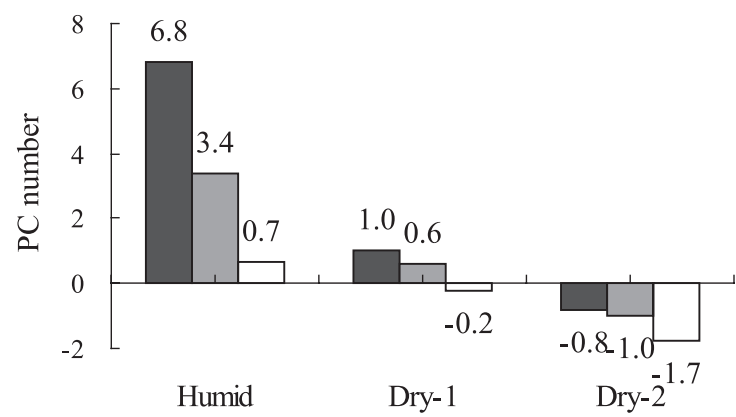

LOKP-2

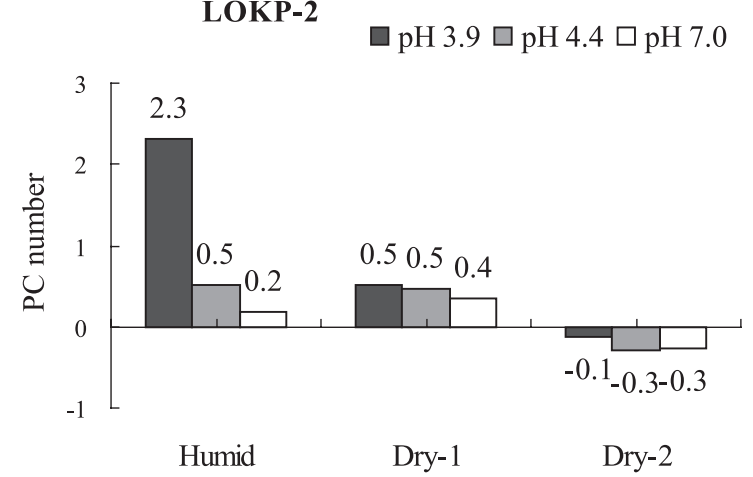

Fig. 2 PC number of LOKP which were treated by accelerated aging tests after acidic or neutral papermaking conditions

ルプ強度を示す一つの指標である。Fig. 5 に示すように LOKP-1 のパルプ粘度は, 湿式劣化後に中性で 4.0 ポイン 卜，酸性側になるほど粘度が低下し，劣化処理前の $1 / 3$ 程 度まで低下した。加熱と加湿の条件に比べると, 日光照射 による粘度の低下は小さかった。

\subsection{HexA 含有量と白色度の関係}

\subsection{1 酸 処 理}

アルカリ条件下のパルプ化の過程でキシランに結合する 4-O-メチルグルクロン酸はHexA に変化する。酸処理に よる HexA の除去については, 池田ら ${ }^{15)}$ が詳細な検討を行 った。酸処理によるHexA 除去は, 処理温度, 時間, pH の影響を受ける。池田らの条件に準じて, 各パルプの HexA の除去を行い, 本実験においても, 処理温度 $105^{\circ} \mathrm{C}, \mathrm{pH}$ 2.5-3.0の条件で処理時間が 3 時間で約 $98 \%$ ，2 時間では 約 $85 \% ， 1$ 時間で約 $60 \%$ が除去される結果が確認された。

\subsubsection{TCF 漂白パルプ}

LOKP-2(71.0\% ISO), 過酸化水素で一回漂白した semi -TCF LOKP-2 (約 80\% ISO), 三回漂白した full-TCF LOKP-2（約 88\% ISO）の三種類の TCF パルプを用いて, 湿式および乾式加速劣化における白色度と HexA 含有量 の関係について検討した。Fig. 6,7 に LOKP-2 と semi$\mathrm{TCF}$ パルプの湿式劣化また乾式加熱劣化後の PC 価の結 果を示す。Fig. 8 には, 三つの加速劣化条件下での full$\mathrm{TCF}$ パルプの $\mathrm{PC}$ 価を示す。
TMP

$\square$ pH $3.9 \square \mathrm{pH} 4.4 \square \mathrm{pH} 7.0$

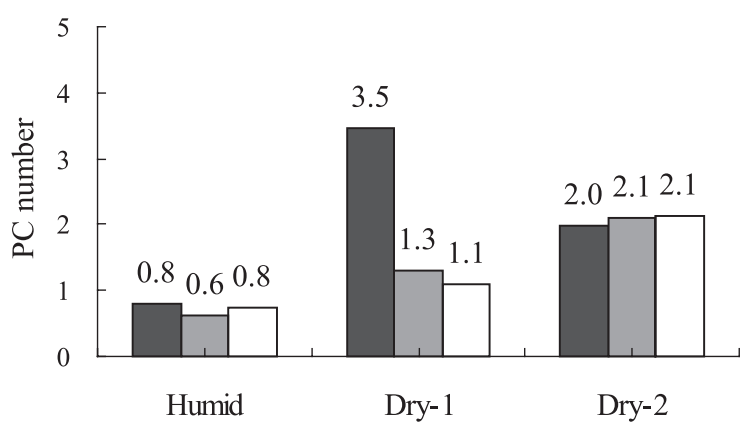

ВСТМP

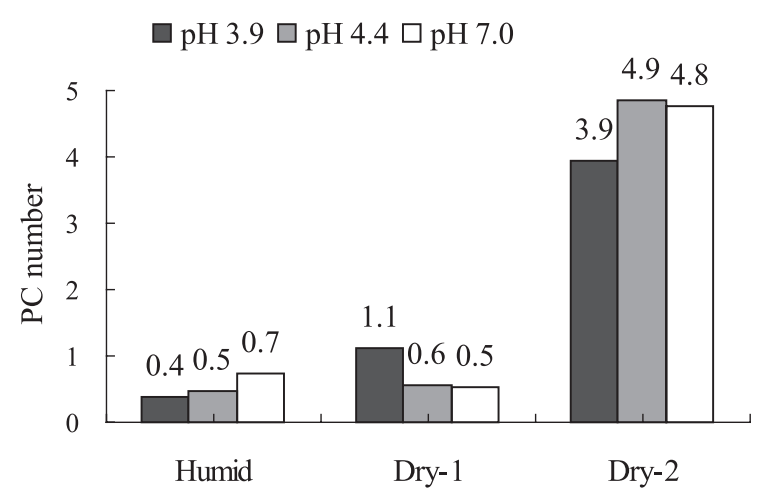

Fig. 3 PC number of TMP which were treated by accelerated aging tests after acidic or neutral papermaking conditions

湿式劣化条件の LOKP-2 試料は, HexA 含有量の高い 試料ほど黄変の大きい傾向がみられ, 特に $\mathrm{pH} 3.9$ では full-TCF の 2 倍以上の PC 価を示した。いずれの試料で も HexA 含有量が元の量の半分程度まで除去されると, 中 性および酸性抄紙の PC 価の差は小さくなった。

一方, 乾式劣化の結果より, HexA 含有量が高いほど変 色が大きい傾向がみられるが，PC 価の変化はきわめて小 さいことがわかった。TCF パルプの結果から, full-TCF パルプは semi-TCF パルプより白色度の安定性が高いこ とが示された（Fig. 7 と Fig. 8 の比較)。

\subsubsection{ECF 漂白パルプ}

酸処理の目的の一つは, 酸処理でHexA を除去するこ とによって，次の漂白段階での HexAによる薬品の消費 を抑え，漂白の効率化を図ることである。しかし，酸処理 と二酸化塩素処理の順序，すなわち A-D シーケンスと D - A シーケンスの違いが，パルプの白色度安定性に与える 影響についてはわかっていない。Table 3 に LOKP-2 を二 段シーケンスで漂白して調製した ECF パルプの白色度と HexA 含有量を示す。Fig.9〜11にはこれらの ECF パル プの $\mathrm{PC}$ 価について, 各種の劣化条件で検討した結果を示 す。両者のシーケンスでも同程度の PC 価であった。湿式 劣化条件 (Fig. 9) では, どちらのシーケンスでも酸性抄 紙で，HexA 含有量の高い試料ほど黄変が大きい傾向がみ 
PPC

$\square \mathrm{pH} 3.9 \square \mathrm{pH} 4.4 \square \mathrm{pH} 7.0$
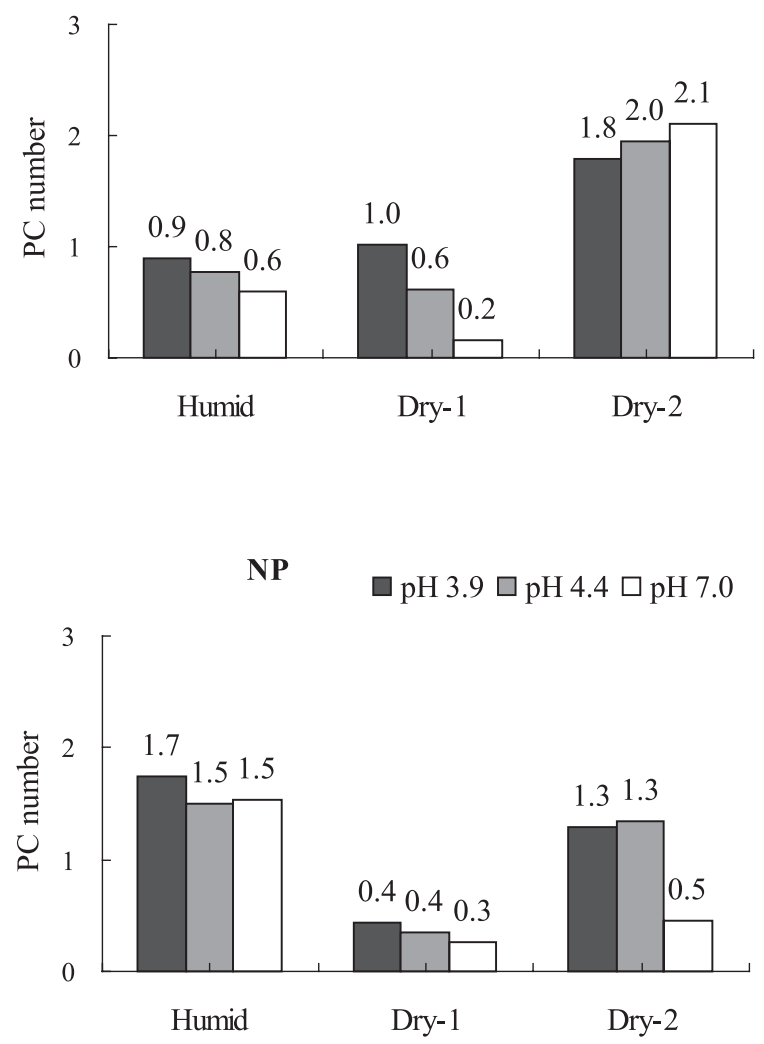

Fig. 4 PC number of recycled paper which were treated by accelerated aging tests after acidic or neutral papermaking conditions

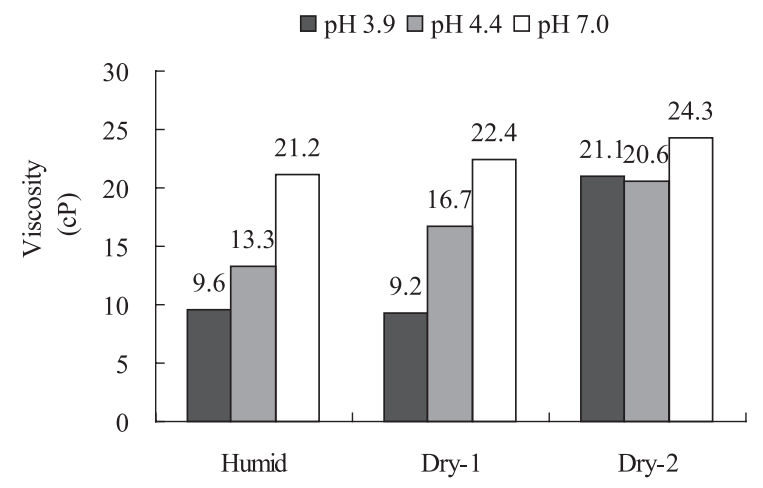

Fig. 5 Viscosity of LOKP-1 which were treated by accelerated aging tests after acidic or neutral papermaking conditions

られ，特に酸性抄紙は中性抄紙の約 2 倍の PC 価を示した。 HexA 含有量が元の半分ぐらいまで除去されると, 中性お よび酸性抄紙の PC 価の差は非常に小さくなった。一方, 乾式劣化条件（Fig. 10）では, ECF パルプの中性抄紙試 料はほとんど白色度低下を示さず，また日光照射による劣 化条件（Fig. 11）では, 酸性抄紙は中性より安定な白色度 を保持した。
LOKP-2

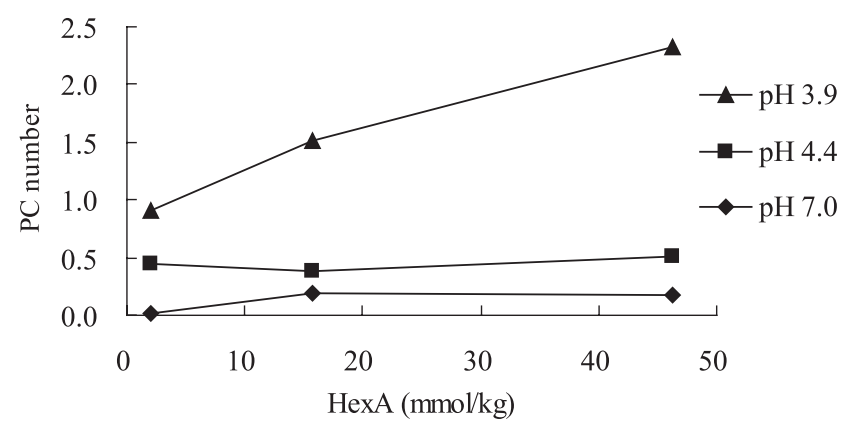

Semi-TCF

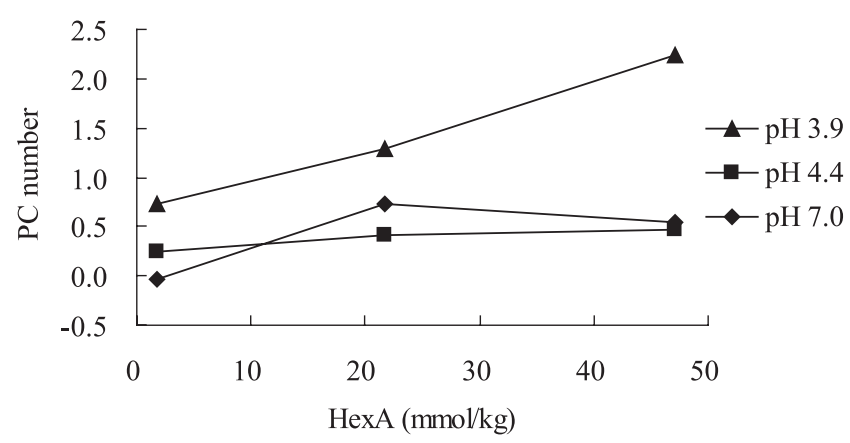

Fig. 6 Relationship between HexA content and PC number of LOKP-2 or semi-TCF which were treated by accelerated aging tests after acidic or neutral papermaking conditions

Table 3 Brightness and HexA content of ECF bleached LOKP-2

\begin{tabular}{ccccccc}
\hline & \multicolumn{2}{c}{ HexA $(\mathrm{mmol} / \mathrm{kg})$} & \multicolumn{3}{c}{ Brightness (\% ISO) } \\
\cline { 2 - 7 } Sequence & \multicolumn{2}{c}{ Time for A treatment $(\mathrm{h})$} & \multicolumn{2}{c}{ pH of papermaking } \\
& 0 & 1 & 2 & 3 & $\mathrm{pH} \mathrm{7.0}$ & $\mathrm{pH} 3.9$ \\
\hline A-D & 43.3 & 16.6 & 2.10 & 0.60 & 88.6 & 88.1 \\
D-A & 42.1 & 16.8 & 2.53 & 0.62 & 88.4 & 88.4 \\
\hline
\end{tabular}

\subsubsection{TCF 漂白パルプと $\mathrm{ECF}$ 漂白パルプの白色度低 下の比較}

パルプは加速劣化処理により, 特に湿式劣化条件の処理 によって白色度が低下して黄色を带びるが，その程度は抄 紙 $\mathrm{pH}$ またはパルプの漂白方法によって大幅に異なる。 Fig. 12 に示すように, 中性抄紙の条件では, LOKP の PC 価の変化が一番小さく, TCF また ECF 漂白パルプはほぼ 同じ程度であった。一方，酸性抄紙の場合，各々の漂白方 法において HexA 含有量の高い試料ほど黄変が大きい傾 向がみられ, 中性抄紙の約 2 倍の PC 価であった。白色度 の安定性が高い順は, full-TCF $\fallingdotseq \mathrm{ECF}$ ( $\mathrm{A}-\mathrm{D}$ シーケンス $)$ $>\mathrm{ECF}$ (D-A シーケンス) $>$ semi-TCF $>$ LOKP となった。 
LOKP-2

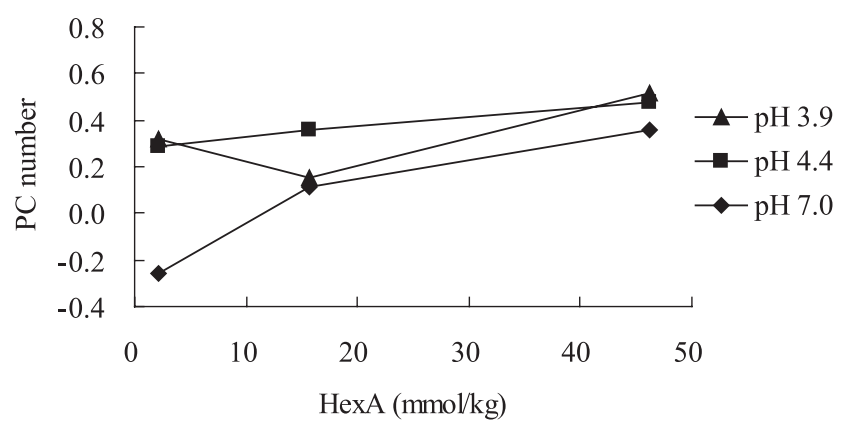

Semi-TCF

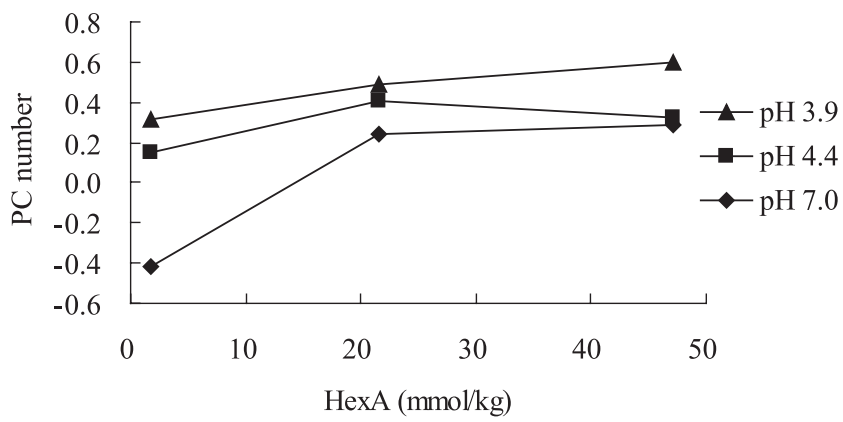

Fig. 7 Relationship between HexA content and PC number of LOKP-2 and semi-TCF which were treated by Dry -1 ageing test after acidic or neutral papermaking conditions

精製度の高いパルプの場合, リグニン残留量は微小であ り，漂白パルプの白色度低下にはほとんど影響しない。し かし, 同じ程度の白色度で比較すると D-A シーケンスの ECF（約 88\% ISO）は full-TCF パルプ（約 86\% ISO）よ り白色度低下が大きかった。 ECF パルプの白色度低下の 原因物質は HexA 由来の物質以外に，パルプに残留する 有機塩素化合物も考えられている。 Rosenau $ら^{8)}$ は Fig. 13 のような構造を過酸化水素漂白段また二酸化塩素漂白段に おける変色物質として挙げている。

パルプ粘度については, 酸処理によって低下することが わかっており, Fig. 14 に示すように, 湿式加速劣化実験 前の粘度は中性抄紙, 酸性抄紙共に D-A シーケンスの ECF が最も低かった。しかし, 湿式加速劣化実験前後の 粘度低下は LOKP-2 酸性抄紙の粘度低下（5.2 ポイント） が最も大きいことがわかった。

\section{5 パルプに対するへキセンウロニダーゼ粗酵素液の} 効果

\subsection{1 ヘキセンウロニダーゼ活性測定}

本研究で用いるへキセンウロニダーゼ活性の測定法は, 五味らによって有効であることが示唆されている ${ }^{11}$ 。その ため, 前項 2.13 に示した方法によって以後の活性測定を 行った。HPAEC-PAD 法による定量分析では, 酵素反応 液とブランク間の有意な差異を確認した（Fig. 15）。すな
(A)
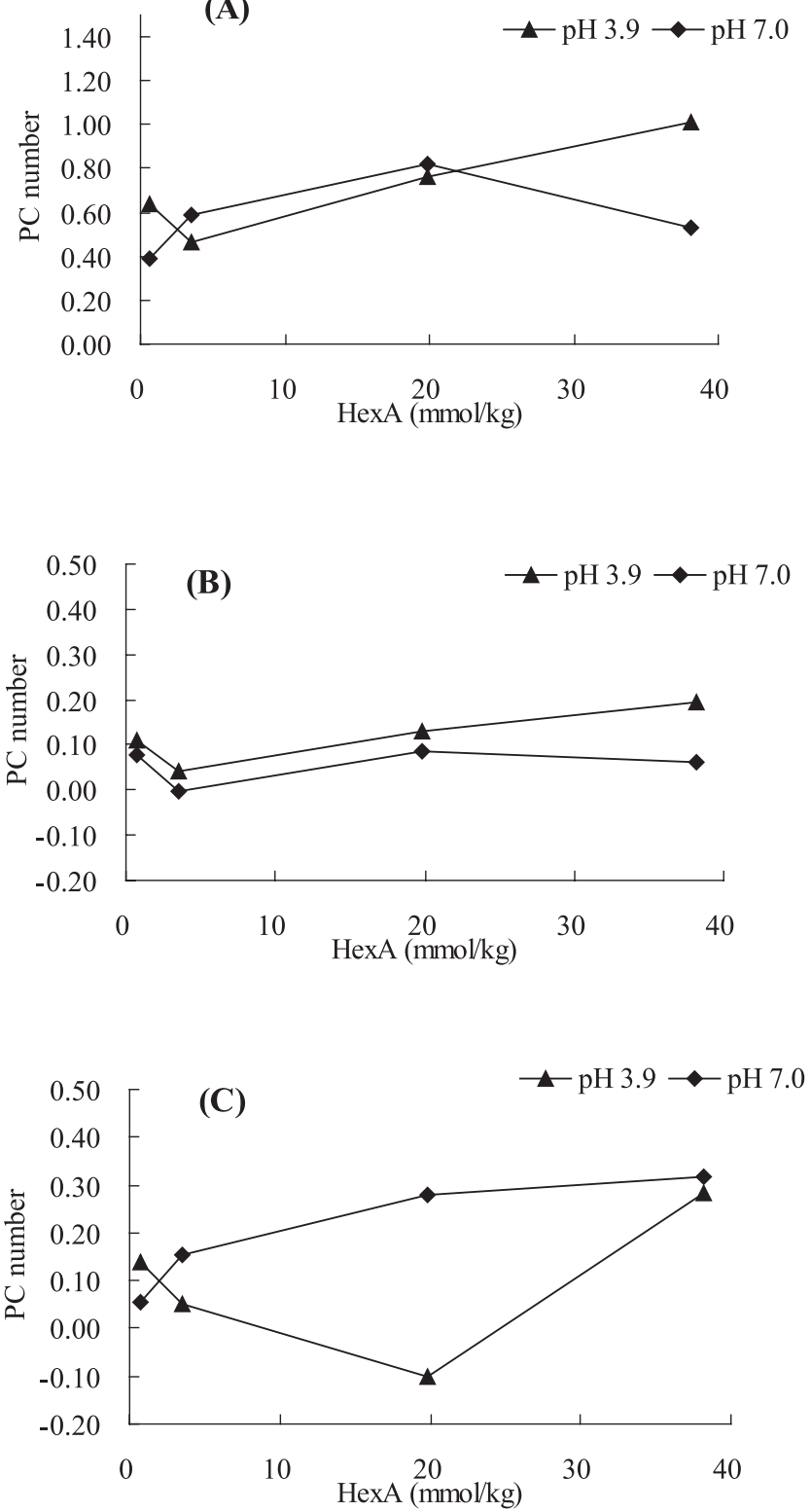

Fig. 8 Relationship between HexA content and PC number of full-TCF which were treated by (A) Humid, (B) Dry -1 , and (C) Dry -2 ageing tests after acidic or neutral papermaking conditions

わち, 粗酵素液を 10-200 倍に希釈し, 各酵素濃度におけ る $\Delta-\mathrm{X}_{3}$ の分解量を求め, この結果から希釈率による濃度 依存的直線を得ることができた。

\subsection{2 ヘキセンウロニダーゼ粗酵素液の添加量}

五味らの結果によると，粗酵素液中のへキセンウロニダ 一ゼは pH 5.0-8.0，30ㄷ，12 時間の処理に対して安定で あった。最適温度が $35-40^{\circ} \mathrm{C}$ であることも明らかとなって いることから，本実験ではパルプに対する処理条件は $\mathrm{pH}$ 5.5 , 温度 $40^{\circ} \mathrm{C} ， 6$ 時間を設定し，パルプ中の HexA 除去 効果について調べた。

活性 $0.04 \mathrm{U} / \mathrm{ml}$ と $0.09 \mathrm{U} / \mathrm{mL}$ の粗酵素液(2)を用い, $1 \mathrm{~g}$ (絶乾換算）の LOKP-2 に対し，それぞれ $0 ， 0.08 ， 0.16$, 0.20，0.24，0.28，あるいは $0.32 \mathrm{U}$ の粗酵素液を加え， 


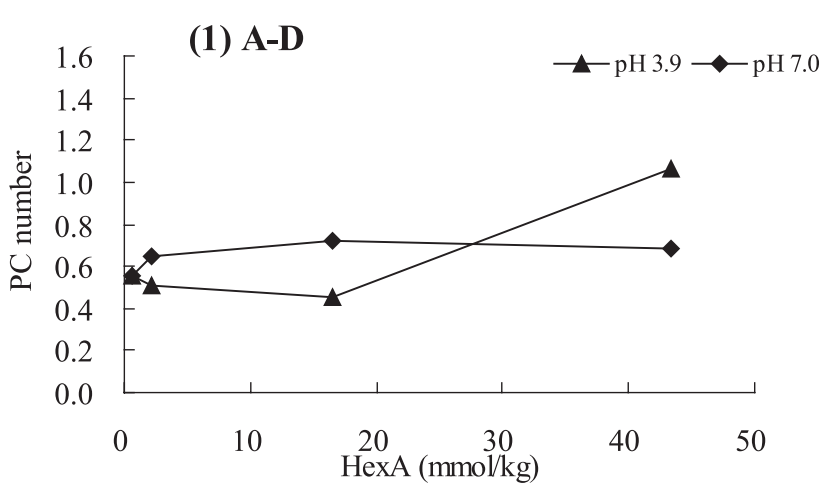

(2) D-A

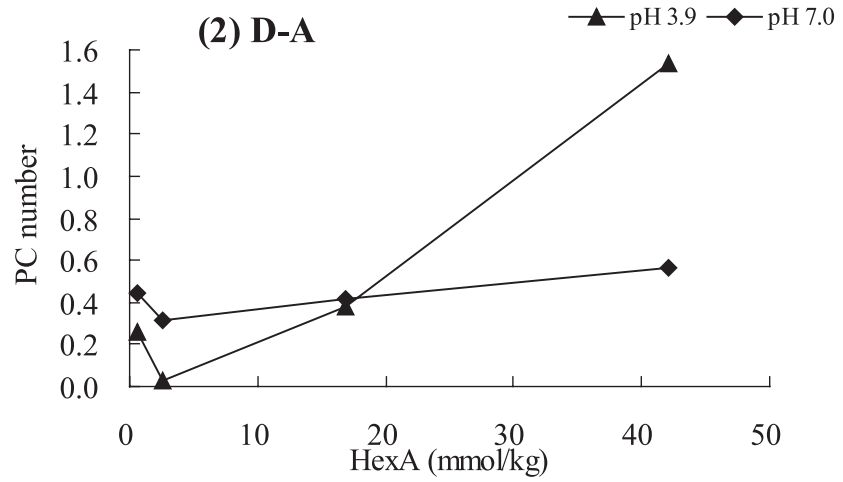

Fig.9 Relationship between HexA content and PC number of ECF bleached LOKP-2 which were treated by Humid ageing test after acidic or neutral papermaking

$\mathrm{pH} 5.5$, 温度 $40^{\circ} \mathrm{C}, 6$ 時間で反応させた後, パルプの HexA 含有量およびパルプのろ液を定量分析した。パルプ中の HexA 残留量の結果を Fig. 16 に示す。酵素の添加量を増 やすとともに, HexAの除去効果が大きくなり $0.24 \mathrm{U} / \mathrm{g}$ で最大值になった。さらに酵素の添加量を増加すると, 0.28 $\mathrm{U} / \mathrm{g}$ と $0.32 \mathrm{U} / \mathrm{g}$ の結果では, HexA 除去能力は逆に低く なり，効果がほとんどみられなくなった。その理由につい ては現在検討を進めている。

一方，酵素処理後のろ液を分析した結果を Fig. 17 に示 す。ろ液中のキシロース濃度は酵素添加量の増加とともに 高くなった。パルプ $1 \mathrm{~kg}$ に対してキシロースの生成量を 計算したところ, 添加量 $0.24 \mathrm{U} / \mathrm{g}$ では, 約 $20 \mathrm{mmol} / \mathrm{kg}$ の HexA が除去されると同時に, 約 $40 \mathrm{mmol} / \mathrm{kg}$ のキシロ ースが生成した（Fig. 18）。

\section{5 .3 処理時間の影響}

前項 3.5.2 では, 酵素添加量 $0.24 \mathrm{U} / \mathrm{g}, \mathrm{pH} \mathrm{5.5}, 40^{\circ} \mathrm{C}$, 6 時間の条件でパルプを処理すると HexA の除去量が多く なる結果が得られた。しかしながら，処理時間をさらに延 長して HexA の除去効果について調べているが， 6 時間の 処理よりも明確に良い結果が得られていない。今後，9-12 時間の処理についてさらに調べる必要がある。一方, 酵素 処理したパルプのろ液を分析では，処理時間を長くすると 分解されたキシロースの濃度が直線的に高くなった (Fig. 19)。ヘキセンウロニダーゼによるへキセンウロン
(1) A-D

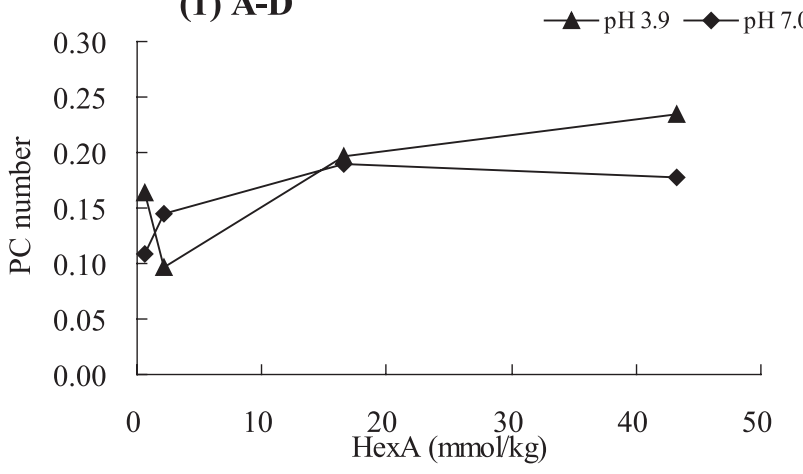

(2) D-A

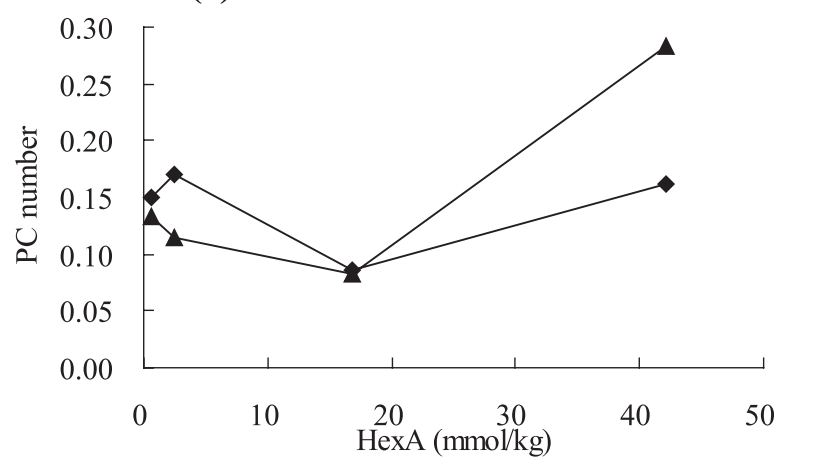

Fig. 10 Relationship between HexA content and PC number of ECF bleached LOKP-2 which were treated by Dry -1 ageing test after acidic or neutral papermaking

酸残基の除去機構については, 現在もさらに研究を進めて いる。粗酵素液に含まれるキシロシダーゼの作用機構につ いても現在検討中である。

\section{5 .4 酵素処理後のパルプ収率}

酵素添加量 0-0.32 U/g, pH 5.5, 温度 $40^{\circ} \mathrm{C}, 6$ 時間条 件で反応させた後のパルプ収率を Fig. 20 に示す。パルプ 収率の減少は, 酵素を添加しない場合と比較して極めて小 さかった。

3.5.5 ヘキセンウロニダーゼ粗酵素液のへキセンウロ ニダーゼ活性安定性

新しい粗酵素液(2)を抽出した日から，失活までの期間を 把握するために，一週間に一回，粗酵素液の活性を測定し た。四週間の活性の変化を Fig. 21 に示す。最初の一週間 で酵素の活性は元の半分まで減少した。四週間後, 粗酵素 の活性は最初の $10 \%$ になった。へキセンウロニダーゼ粗 酵素液(2は, 抽出してから一週間以内に使用するのであれ ば，パルプの処理有効に利用できることがわかった。

4. 結 論

HexA 含有量が高いLOKP（白色度 $71.0 \%$ ISO）から 酸性抄紙条件で調製したパルプの湿式加速劣化試験では, 乾式加速劣化に比べるとパルプ白色度の低下が大きかった。 日光照射劣化では白色度が向上する現象が認められた。

日光照射劣化では，木材とほぼ同じ特徴のリグニンを有 


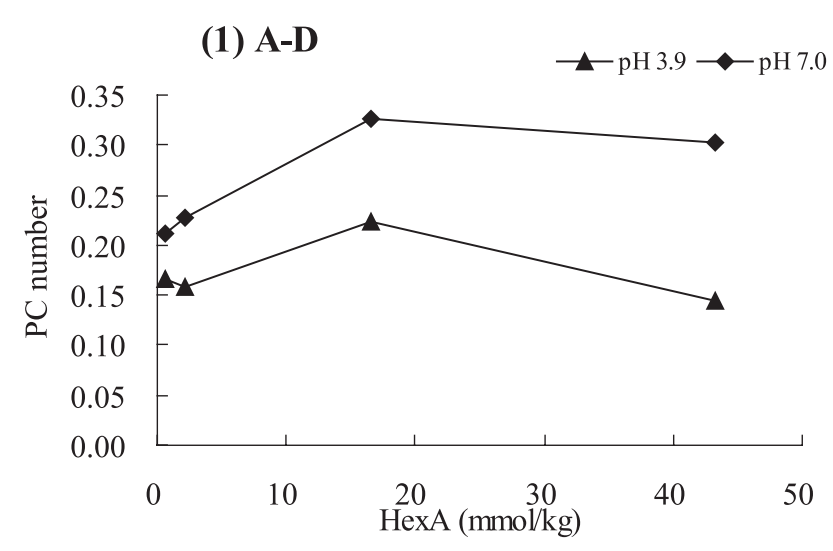

(2) D-A

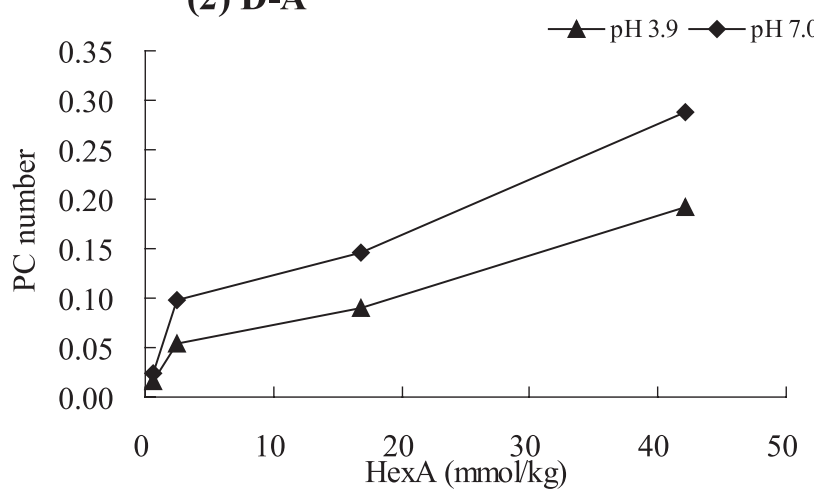

Fig. 11 Relationship between HexA content and PC number of ECF bleached LOKP-2 which were treated by Dry- 2 ageing test after acidic or neutral papermaking
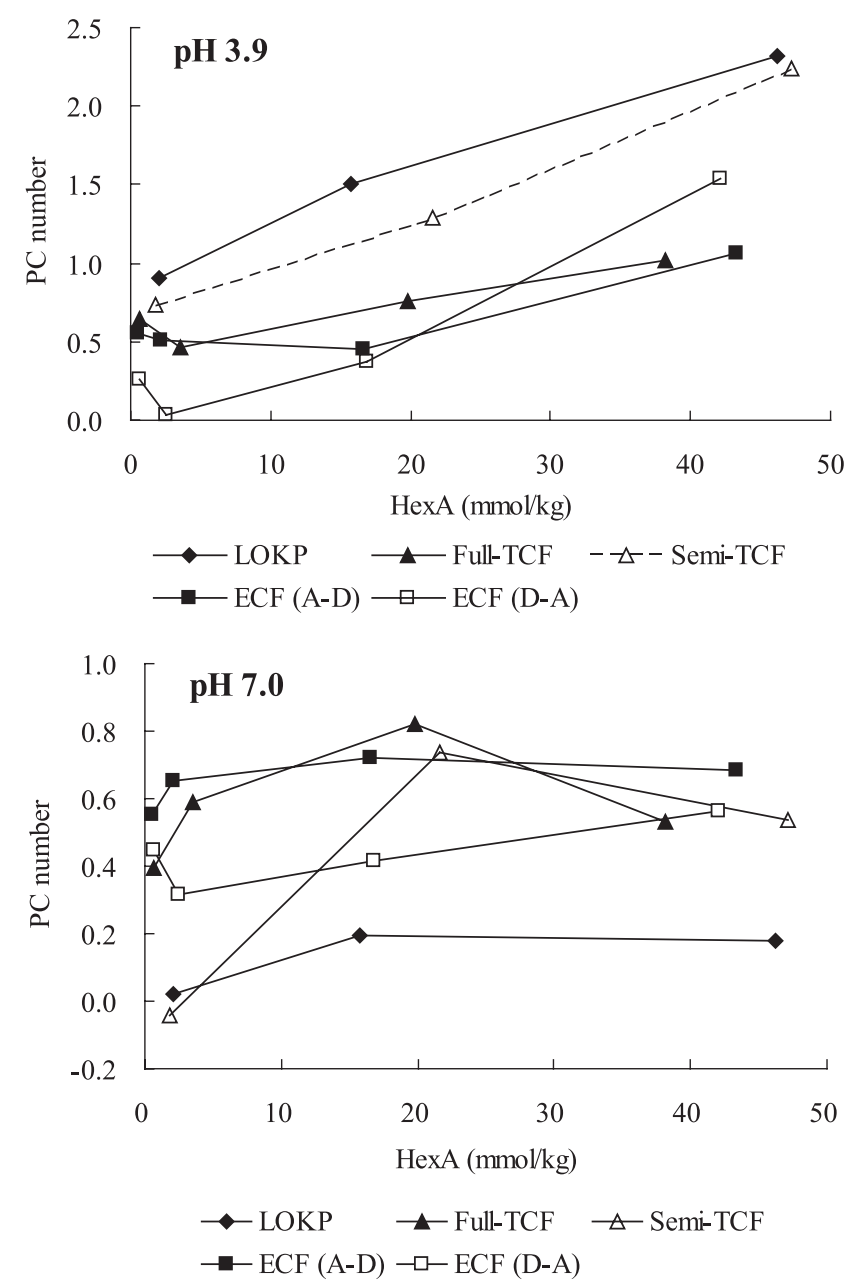

Fig. 12 Relationship between HexA content and PC number of various bleached LOKP which were treated by humid ageing test after acidic or neutral papermaking conditions

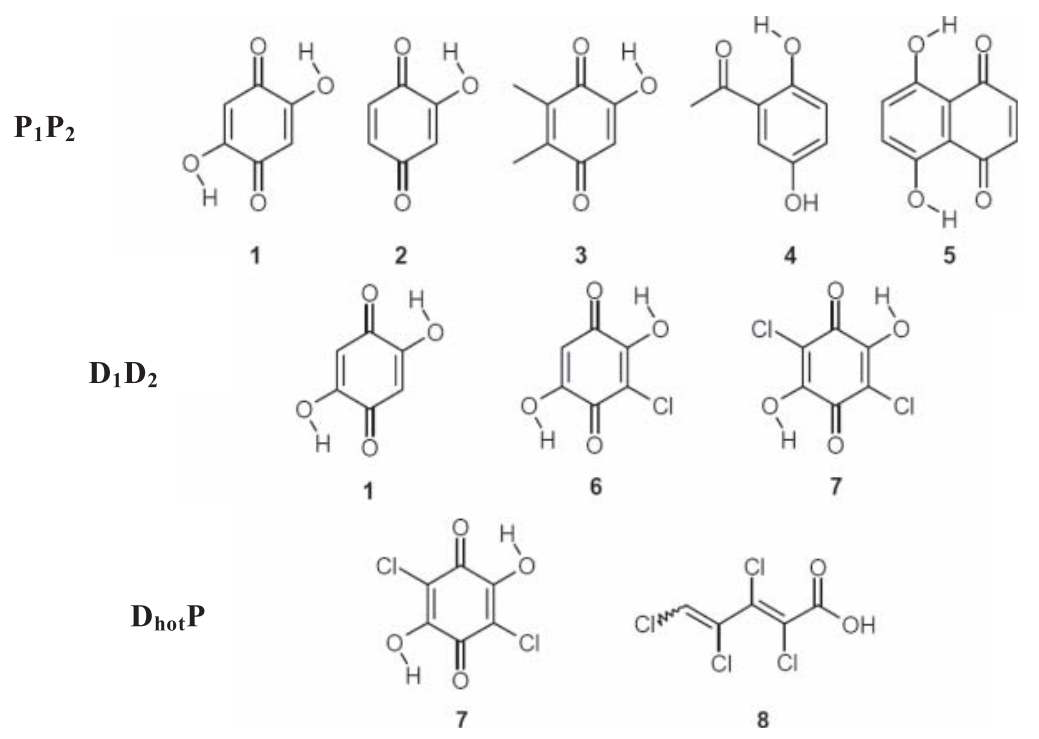

Fig. 13 Chromophores isolated from pulp bleached finally with $\mathrm{P}_{1} \mathrm{P}_{2}, \mathrm{D}_{1} \mathrm{D}_{2}$, and $\mathrm{D}_{\text {hot }} \mathrm{P}$ (Rosenau and others, 2007, ref. 9) 


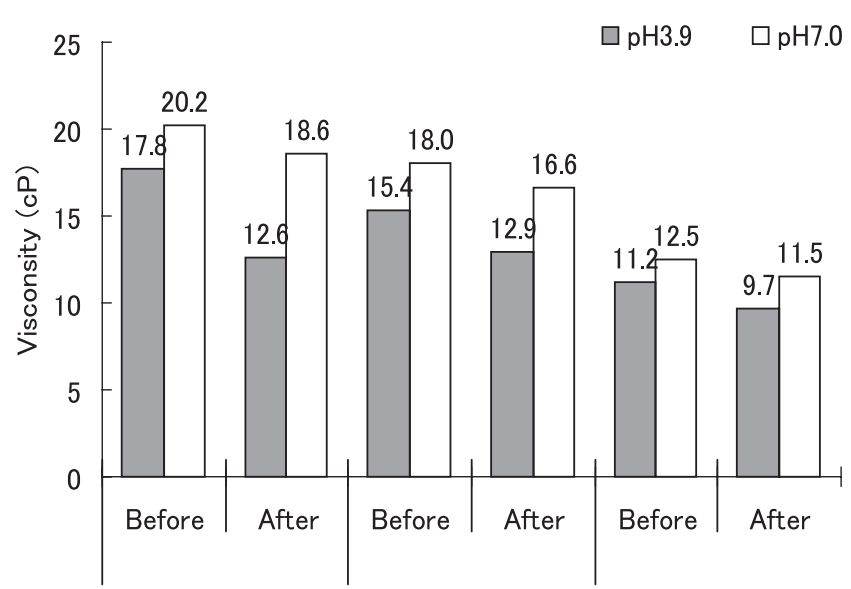

Fig. 14 Change in pulp viscosity of LOKP, semi-TCF, and ECF ( $D-A$ sequence) which were treated by humid ageing test after acidic or neutral papermaking
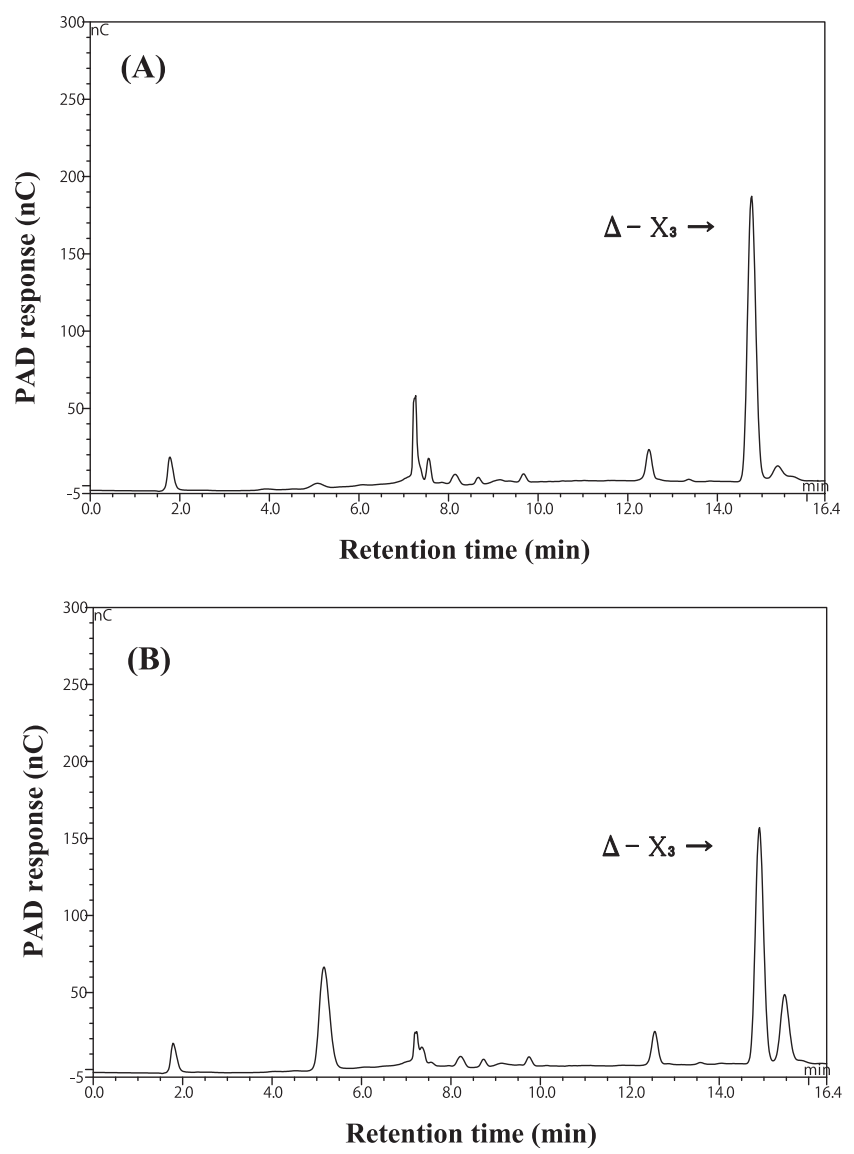

Fig. 15 HPAEC chromatograms of enzymatic treatment with $\Delta-\mathrm{X}_{3}$

(A) Control, (B) Reaction mixture

する TMP と BCTMP のリグニンは着色構造へ変化するが, 酸性抄紙による白色度低下への影響は小さかった。

古紙含有の PPC と NP には, 化学パルプと機械パルプ の両方が配合されていると考えられ，劣化处理の条件およ び抄紙時の $\mathrm{pH}$ にかかわらず, 白色度は比較的安定性で
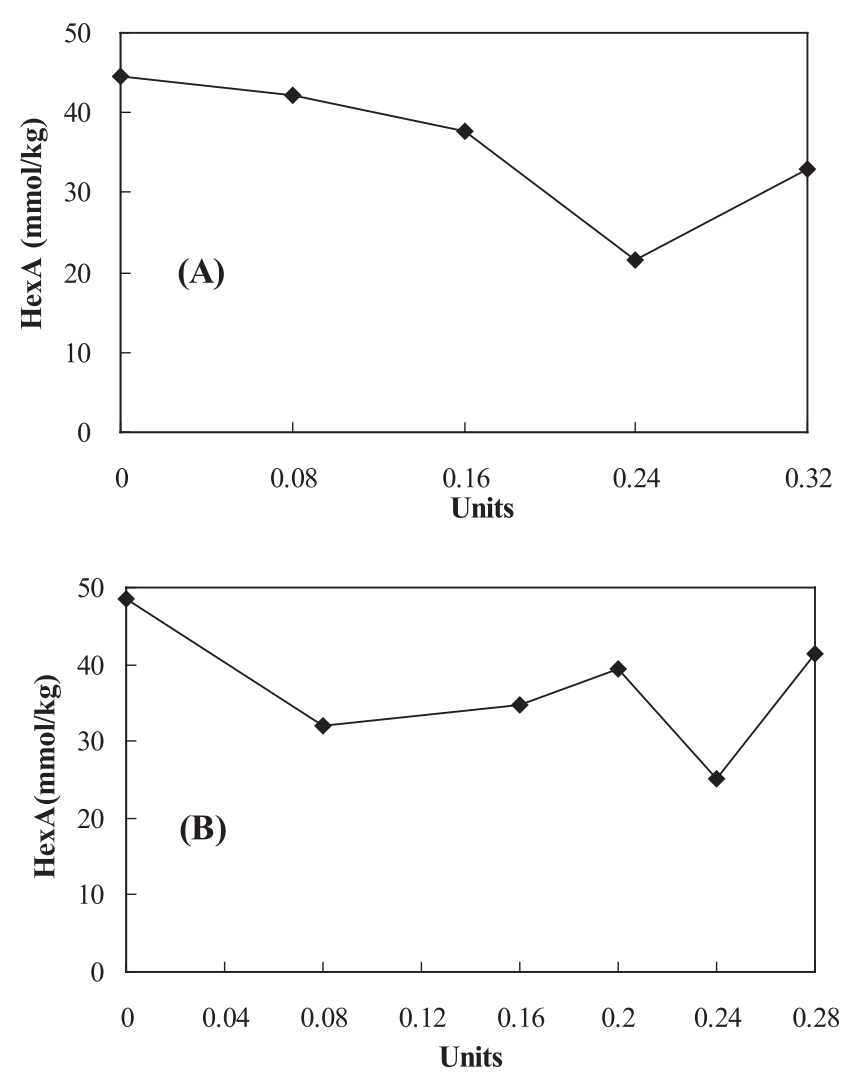

Fig. 16 Relationship between HexA content of LOKP and charged units of hexenuronidase per gram of pulp in crude enzyme solution after enzymatic treatment at $40^{\circ} \mathrm{C}$ for $6 \mathrm{~h}$

Legend: (A) : Activity of hexenuronidase in a crude enzyme solution, $0.04 \mathrm{U} / \mathrm{mL}$, (B) : Activity of hexenuronidase in a crude enzyme solution, $0.09 \mathrm{U} / \mathrm{mL}$

あった。

中性抄紙の場合では, LOKP の白色度低下が一番小さ く, TCF 拈よび $\mathrm{D}-\mathrm{A}$ シーケンスの $\mathrm{ECF}$ 漂白パルプはほ ぼ同程度であった。酸性抄紙の場合, これらのパルプの HexA 含有量が高いほど黄変が大きい傾向がみられた。白 色度の安定性が高い順から full- $\mathrm{TCF} \fallingdotseq \mathrm{ECF}$ ( $\mathrm{A}-\mathrm{D}$ シーケ ンス) $>\mathrm{ECF}(\mathrm{D}-\mathrm{A}$ シーケンス) $>\mathrm{semi}-\mathrm{TCF}>\mathrm{LOKP}$ の 順となった。

パルプ粘度の低下は, LOKP 酸性抄紙の湿式加速劣化 後が一番大きかった。

ヘキセンウロニダーゼ（ $\Delta-\mathrm{X}_{3}$ 活性）粗酵素液を用いた LOKP 中の HexA の除去効果については, 酵素添加量 0.24 $\mathrm{U} / \mathrm{g}, \mathrm{pH} 5.5,40^{\circ} \mathrm{C}, 6$ 時間のパルプ処理を行うと, 最も 良い結果が得られた。パルプから約 $20 \mathrm{mmol} / \mathrm{kg}$ の HexA が除去される時に, 約 $40 \mathrm{mmol} / \mathrm{kg}$ のキシロースが生成し たが，パルプ収率の低下は極めて小さかった。へキセンウ ロニダーゼ粗酥素液の $\Delta-X_{3}$ 活性は, 抽出してから一週間 後に約 $50 \%$ まで減少するが, 粗酵素液を抽出してから一 週間以内に使用するのであれば，パルプの HexA 除去処 理で良い結果が得られた。 


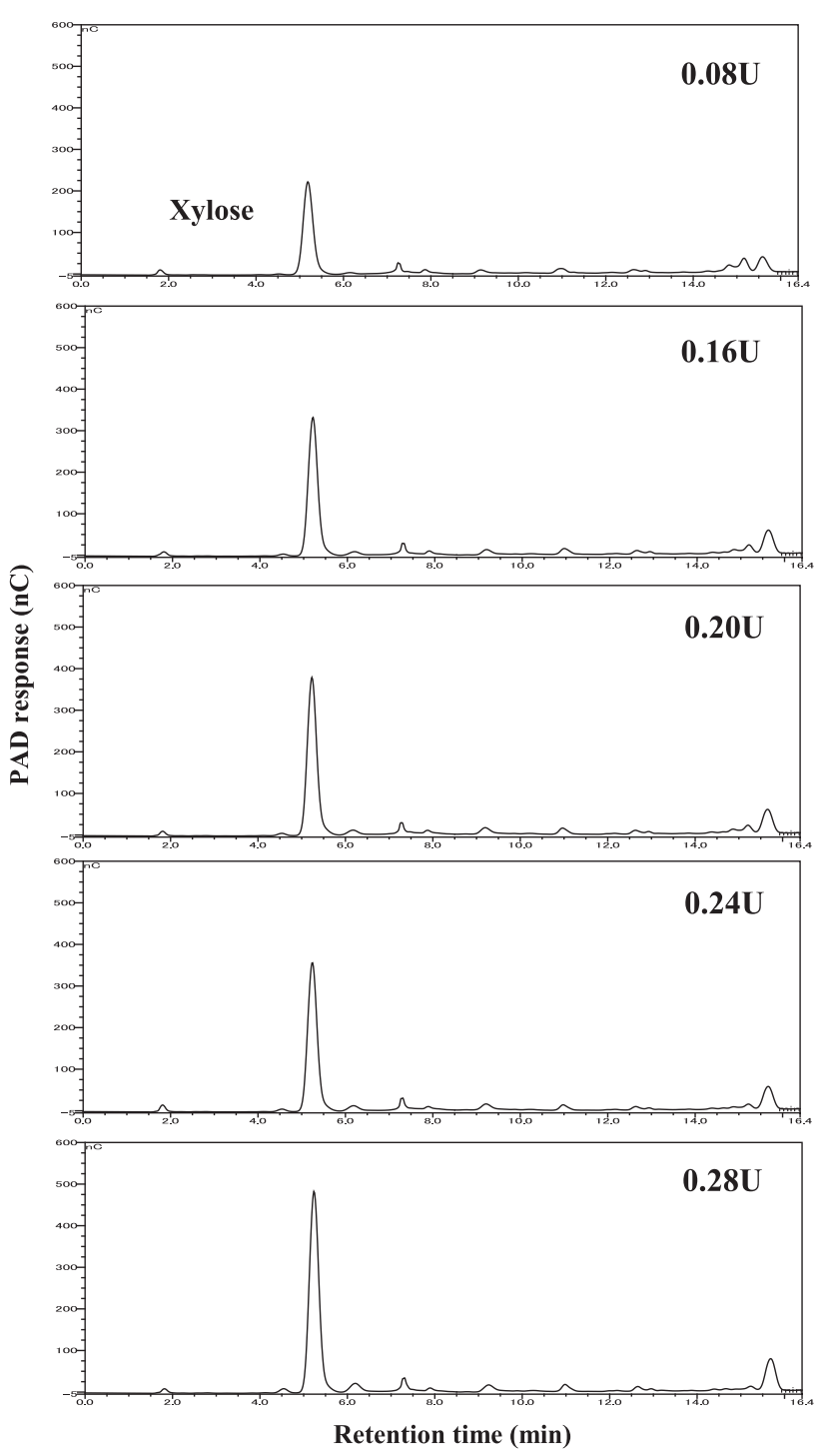

Fig. 17 HPAEC chromatograms of filtrate after enzymatic treatment at $40^{\circ} \mathrm{C}$ for $6 \mathrm{~h}$

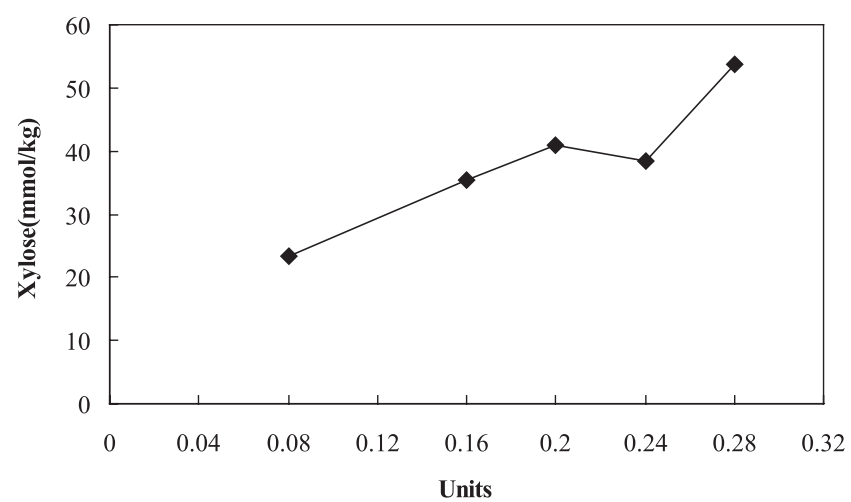

Fig. 18 Relationship between xylose amount dissolved into filtrate and charged hexenuronidase units per gram of pulp after enzymatic treatment at $40^{\circ} \mathrm{C}$ for $6 \mathrm{~h}$

Legend : Xylose amount is shown as mmol per kilogram of LOKP

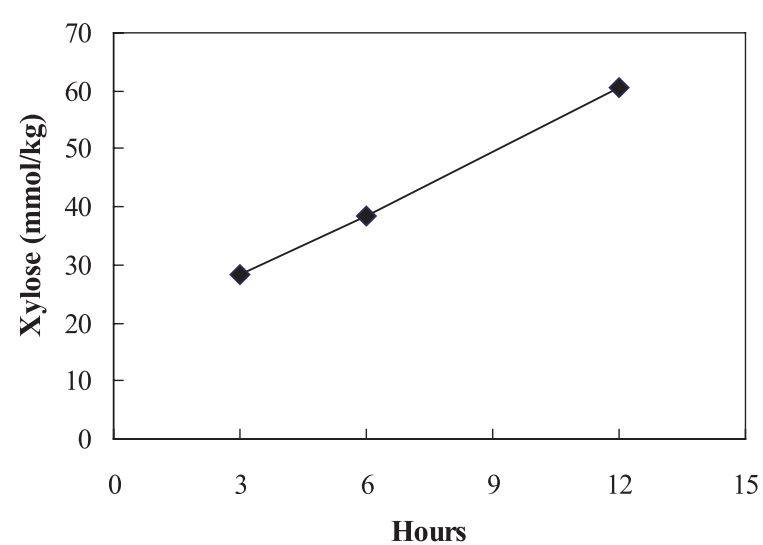

Fig. 19 Relationship between xylose amount dissolved into filtrate and duration of enzymatic treatment at $40^{\circ} \mathrm{C}$ with $0.24 \mathrm{U} / \mathrm{g}$ of hexenuronidase

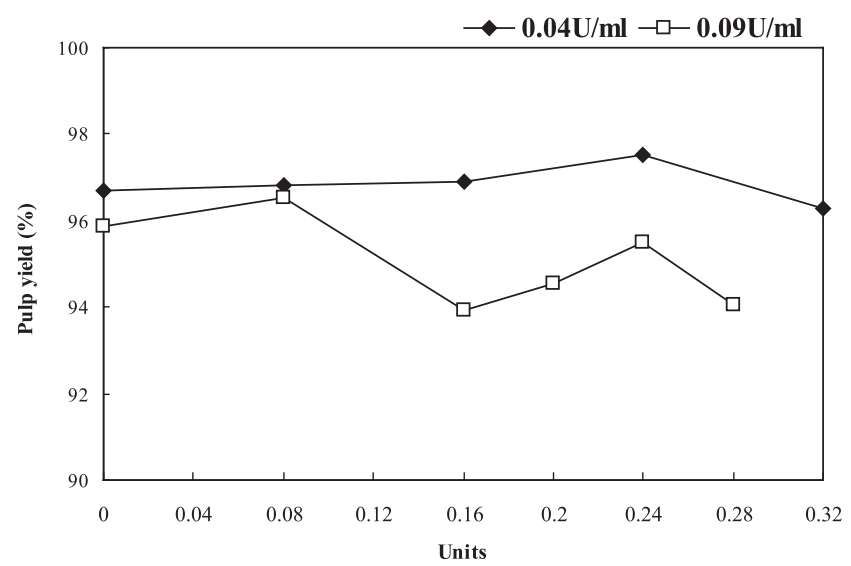

Fig. 20 Relationship between pulp yield and charged units of hexenuronidase per gram of pulp after enzymatic treatment at $40^{\circ} \mathrm{C}$ for $6 \mathrm{~h}$

Legend : Activity of hexenuronidase in a crude enzyme solution

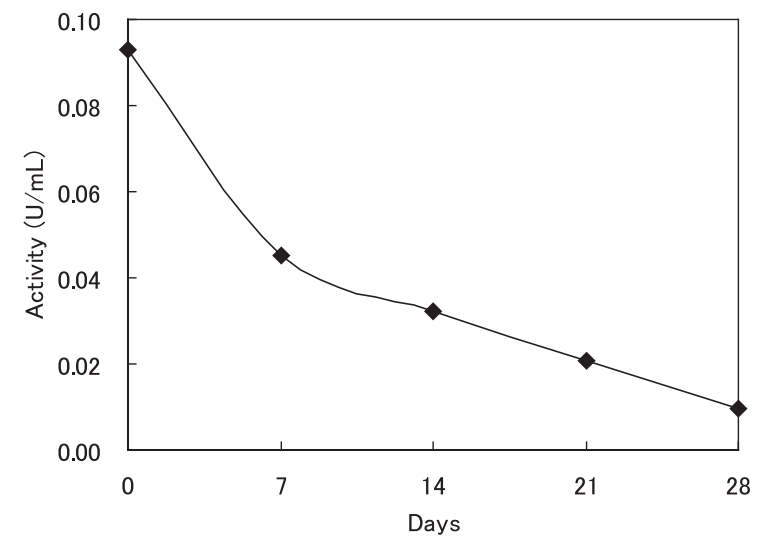

Fig. 21 Changes in activity of hexenuronidase in a crude enzyme solution 
Acknowledgements

本研究を行うにあたり, 筑波大学生命環境科学研究科国 際地縁技術開発科学専攻土居修一教授, 中川明子助教およ び生物機能化学専攻吉田滋樹准教授には, 実験のご指導い ただきまして，また吉田研究室の皆様からは貴重な菌体と 試料を恵与いただきましたことを深く感謝申し上げます。

\section{References}

1）紙パルプ技術協会編：パルプ漂白の一般的原理，「パ ルプ処理および漂白」, 紙パルプ技術協会編, 東京, 1967, pp 85-277

2) Vurorinen T., Telman A., Fagerström P., Buchert J., Tenkanen M. : Selective hydrolysis of hexenuronic acid groups and it's application in ECF and TCF bleaching kraft pulps. International Pulp Bleaching Conference, Atlanta, 1996, April 14-18, Book 1, 43-51

3) Gellerstedt G., Li J. : An HPLC method for the quantitative determination of hexenuronic acid groups in chemical pulps. Carbohydrate Res. 294, 41-51 (1996)

4) Telman A., Harjunpää V., Tenkanen M., Buchert J., Hausalo T., Drakenberg T., Vuorinen T. : Characterization of $4-\mathrm{O}-$ deoxy $^{-} \beta-\mathrm{L}-$ threo-hex-4-enopyranosyluronic acid attached to xylan in pine kraft pulp and pulping liquor by $1 \mathrm{H}$ and 13 NMR spectroscopy. Carbohydrate Res. 272, 55-71 (1995)

5) Granström A., Eriksson T., Gellerstedt G., Rööst C., Larsson P.: Variables affecting the thermal yellowing of TCF-bleached birch kraft pulps. Nord. Pulp Paper Res. J., 16 (1), 18-23 (2001)

6) Vurorinen T., Fagerström P., Buchert J., Tenkanen M., Telman T.: Selective Hydrolysis of Hexenuronic Acid Groups and its Application in ECF and TCF Bleaching of Kraft Pulps. J. Pulp Paper Science, 25 (5), 155-162 (1999)

7) Kawae A., Uchida Y. : Heat and moisture-induced yellowing of ECF-light bleached hardwood kraft pulp. Appita J., 58 (5), 378-381（2005）

8) Sevastyanova O., Li J., Gellerstedt G. : On the reaction mechanism of the thermal yellowing of bleached chemical pulps. Nord. Pulp Paper Res. J., 21 (2), 188192 (2006)

9) Rosenau T., Potthast A., Koama P., Suess U. H., Nimmerfroh N. : Chromophores in aged hardwood pulptheir structure, sources, and degradation potential. Proc. of the 14 th International Symposium on Wood, Fiber and Pulping Chemistry, Durban, June 25-28, 2007, CD-ID 81.

10) Kuwabara E., Yoshida K., Koshitsuka T. : Peroxymonosulfuric acid treatment of ECF bleaching kraft pulp for prevention of yellowing. Proc. of the 75 th Pulp and Paper Research Conference, Tokyo, June 26 $-27,2008,44-49$.

11）五味真也：新規 HexA 遊離酵素の探索. 筑波大学大 学院生命環境科学研究科修士論文（2009 年 1 月）

12) Tenkanen M., Gellerstedt G., Vurorinen T., Teleman A., Perttula M., Li J., Buchert J. : Determination of hexenuronic acid in softwood kraft pulps by three different methods. J. Pulp and Paper Science, 25 (9), 306 -311 (1999)

13) Telman A., Hausalo T., Tenkanen M., Vuorinen T. : Identification of the acidic degradation products of hexenuronic acid and characterization of hexenuronic acid-substituted xylooligosaccharides by NMR spectroscopy. Carbohydrate Res. 280, 197-208（1996）

14) Ishihara M., Hosoya S. : Action of Rhizopus niveus xylanase on hardwood kraft pulp. Proc. 10 th International Symposium on Wood and Pulping Chemistry Vol. III, Yokohama, June 7-10, 1999, 30-33

15) Ikeda T., Ohi H. : Brightness stability and hexenuronic acid content of totally chrorine-free hardwood bleached pulp. Proc. of the 12 th International Symposium on Wood and Pulping Chemistry, Madison, June 9-12, 2003, Vol. I, 219-222

(受理 : 2012.2.16) 